\title{
Efficacy of Portulaca oleracea supplementation with a combination training program on the levels of some blood factors and health indicators of obese females with non- alcoholic fatty liver disease
}

\author{
Narges Aliniya', Alireza Elmieh ${ }^{2}$, Mohammadreza Fadaei Chafy ${ }^{2}$ \\ ${ }^{1}$ PhD Student of Exercise Physiology, Department of Physical Education and Sport Sciences, Rasht Branch, Islamic \\ Azad University, Rasht, Iran \\ ${ }^{2}$ Assistant Professor, Department of Physical Education and Sport Sciences, Rasht Branch, Islamic Azad University, \\ Rasht, Iran
}

\begin{abstract}
Background: Fatty liver disease is a type of fat aggregation in the liver cells. The Portulaca oleracea plant has hypolipidemic property. The aim of this study was to evaluate efficacy of Portulaca oleracea supplementation with a combination training program on the levels of some blood factors and health indicators of obese females with non- alcoholic fatty liver disease.

Materials and methods: 40 obese women were randomly selected and divided into four groups, including training group $(n=10)$, training + supplement group $(n=10)$, placebo group $(n=10)$, and supplement group $(\mathrm{n}=10)$. The plasma levels of cardiovascular risk factors and health factors were measured before and after the twelve week intervention. The paired samples t- test and ANOVA was used to analyze data.

Results: Portulaca oleracea supplementation with a combination training program significantly reduced cholesterol $(\mathrm{P}=0.001)$, triglycerides $(\mathrm{P}<0.0001)$, LDL $(\mathrm{P}<0.0001)$, fat percentage $(\mathrm{P}<0.0001)$, and waist to hip ratio $(\mathrm{P}<0.0001)$ and a significant increase in serum level of HDL $(\mathrm{P}<0.0001)$, Body fat percentage $(\mathrm{P}<0.0001)$, waist- to- hip ratio $(\mathrm{P}=0.03)$, and $\mathrm{BMI}(\mathrm{P}=0.01)$ in exercise + supplement group, exercise group, and supplement group $(\mathrm{P}<0.05)$.

Conclusion: Portulaca oleracea supplementation with a combination training program can be effective in reducing some blood and health indicators in obese women with non-alcoholic fatty liver.

Keywords: Portulaca oleracea supplementation, Non- alcoholic fatty liver disease, Combined training, Health factors.

Cited as: Aliniya N, Elmieh AR, Fadaei Chafy MR. Efficacy of Portulaca oleracea supplementation with a Combination training program on the levels of some blood factors and health indicators of obese females with Non - Alcoholic Fatty Liver Disease. Medical Science Journal of Islamic Azad University, Tehran Medical Branch 2020; 30(3): 253-266.
\end{abstract}

Correspondence to: Alireza Elmieh

Tel: +989111359121

E-mail: elmieh@iaurasht.ac.ir

ORCID ID: 0000-0002-6266-0018

Received: 14 Oct 2019; Accepted: 27 Nov 2019 
مجله علوم يزشكى دانشكاه آزاد اسلامى

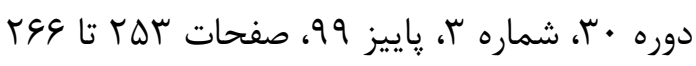

\title{
بررسى تاثير مكمل خرفه همراه با يك دوره برنامه تمرين تركيبى بر سطوح برخى فاكتورهاى خونى و شاخصهاى تندرستى زنان جاق مبتلا به كبد جرب غير غيرالكلى
}

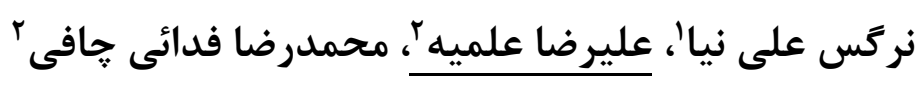

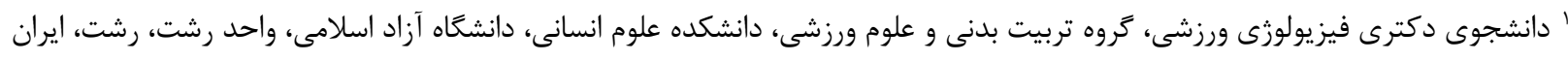

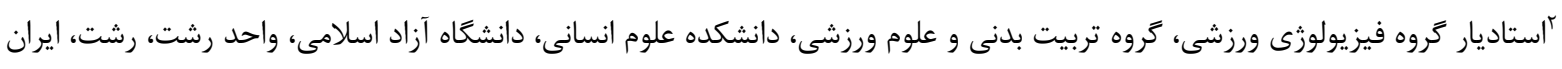

جـكيده

سابقه و هدف: بيمارى كبد جرب غيرالكلى، نوعى تجمع جربى در سلول هاى كبلى است. از آنجايى كه كياه خرفه داراى ويثكى

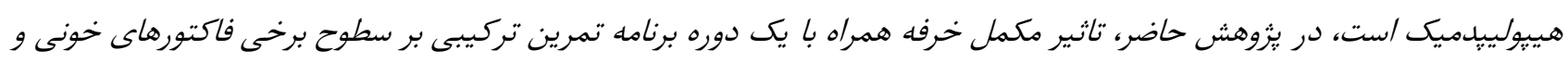

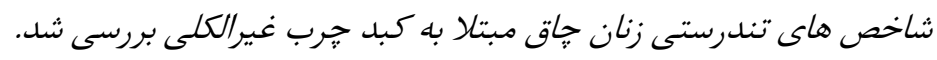

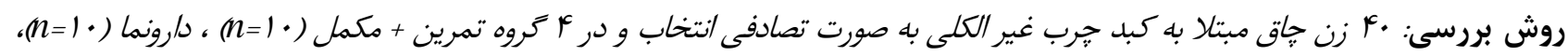

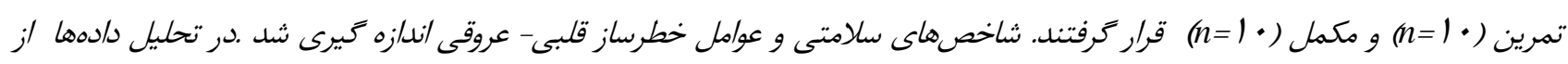

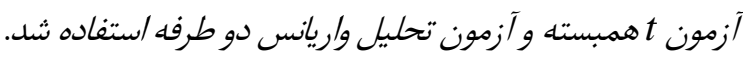

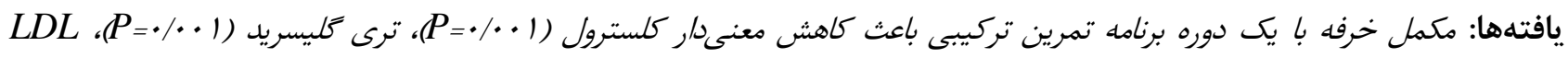
(1)

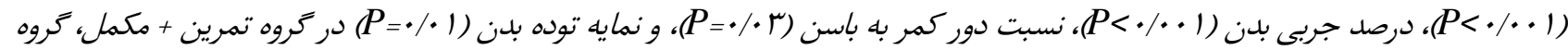

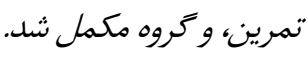

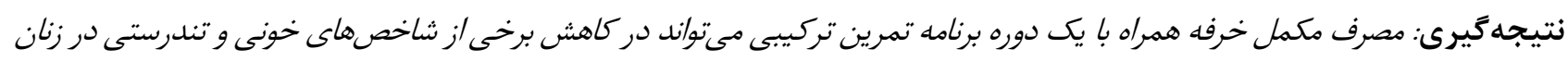

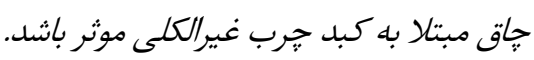

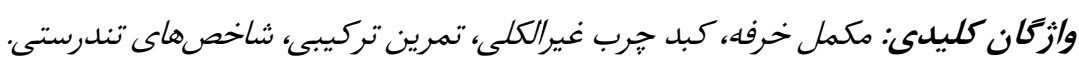

الكلى است (1). كبد خرب غيرالكلى، تجمع خربى به ويزه ترى مقدمه

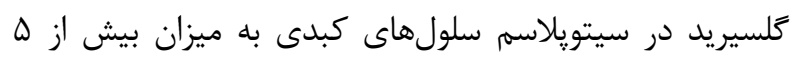

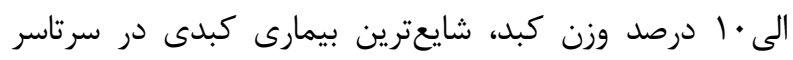

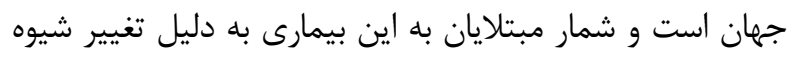

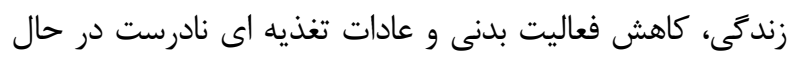

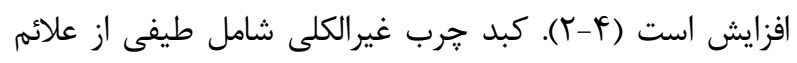

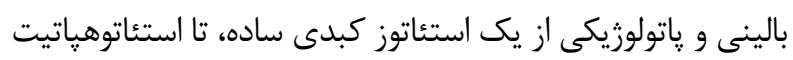

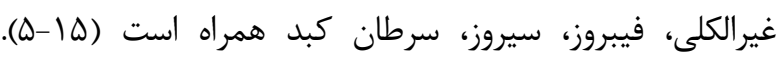

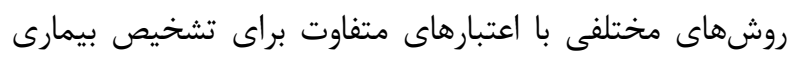

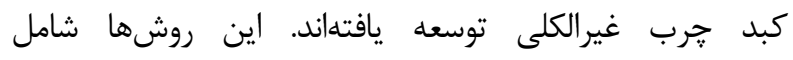

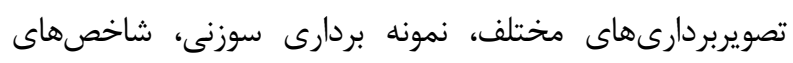

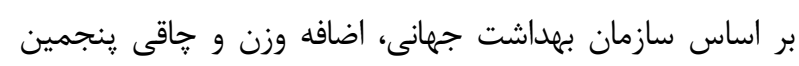

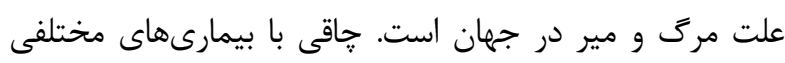

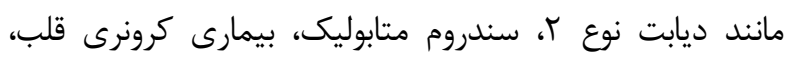

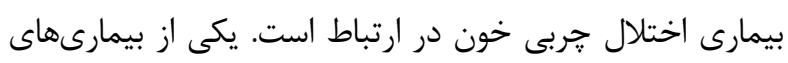

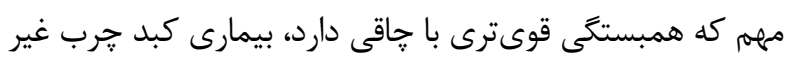

آدرس نويسنده مسئول: رشت، گروه تربيت بدنى و علوم ورزشى، دانشكده علسوم انسانى، دانشـاه آزاد

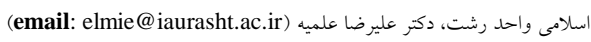
ORCID ID: 0000-0002-6266-0018 تاريخ دريافت مقاله: تاريخ هذيرش مقاله: 9N/9/9 
بقاى سلولهاى آسيب ديده مىشود. خرفه موجب مهار مسير سيخنالينخ فاكتور هستهاى كاياى بى (Factor KB Nuclear) توسط TNF -a و كاهش التهاب مى شود. هميجنين بيان شده كه خرفه به طور موثرى موجب كاهش بيان يروتئين هاى كموتاتيك اينترلوكين A (Interleukin 8) در سطح مونوسيتها به صورت

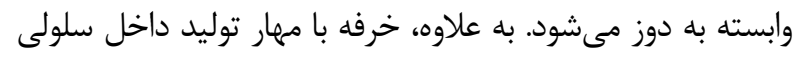

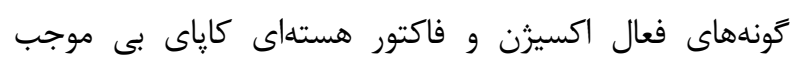

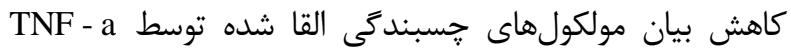

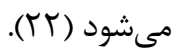

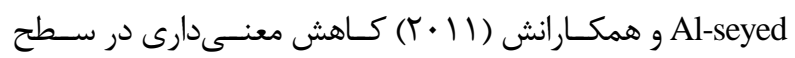
سرمى جربىهاى خـون ( تـرى كلسـيريد، كلسـترول تـام، LDL

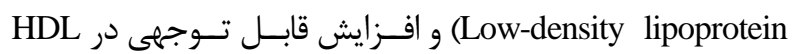

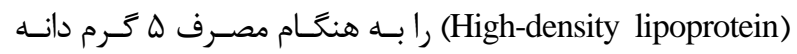

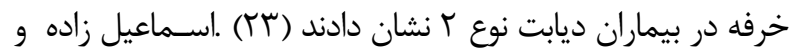

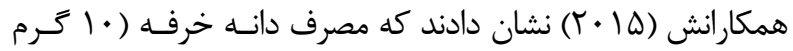

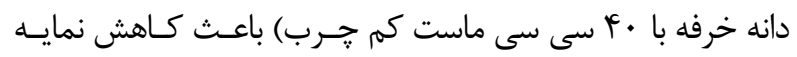

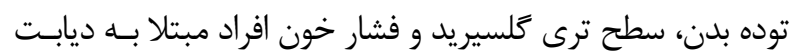

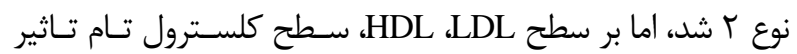

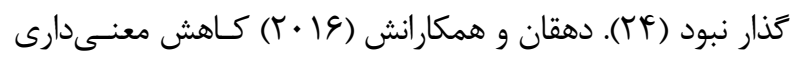

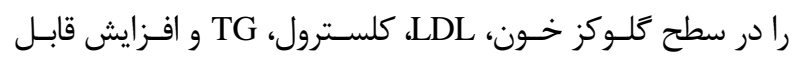
ملاحظهاى را در سطح سرمى HDL، بـر اثـر مصـرف دانـه خرفـه

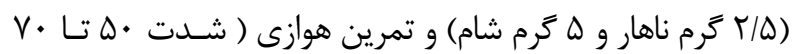

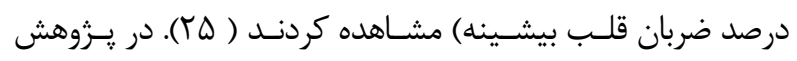

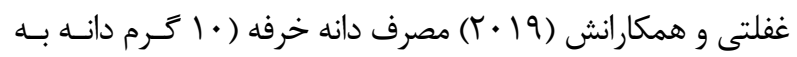

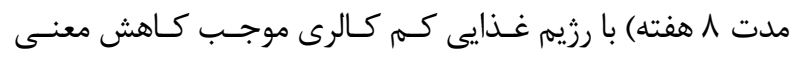

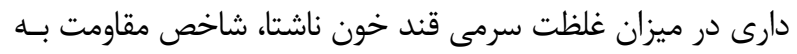

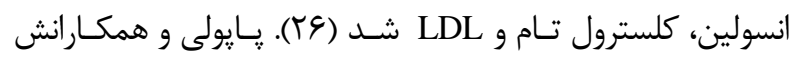

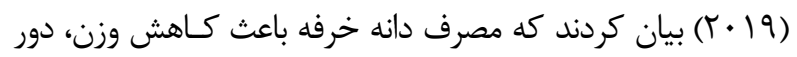

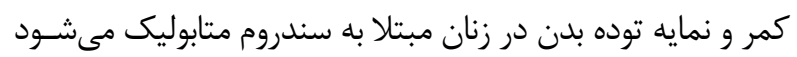

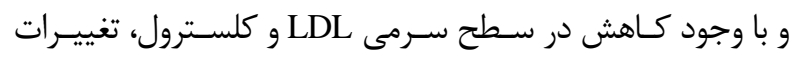

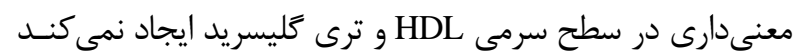

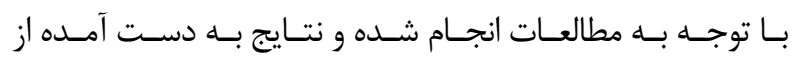
يزوهشهاى بيشين، اطلاعات متناقضى در مورد اثر انسواع تمرينـات

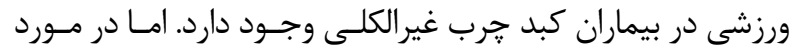

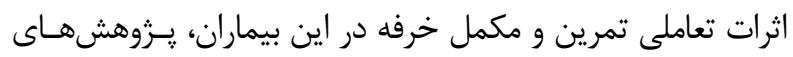

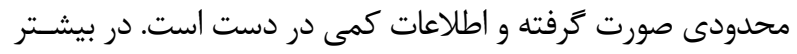
يزوهشهاى انجام شده نيز از دانه خرفه استفاده شده بود. با توجـهـ به خواص درمانى قسمتهاى مختلـف كيـاه خرفـه (دانسه، سـاقه،

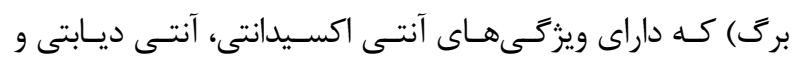

بيوشيميايى و آنترويومتريك هستند. متداولترين و قابل اجراترين روش ارزيابى براى تشخيص اين بيمارى، بالا بودن غلظت

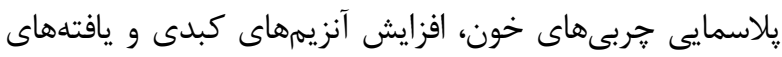
سونوكرافى هستند (1). مطالعات نشان دادهاند كه فعاليت

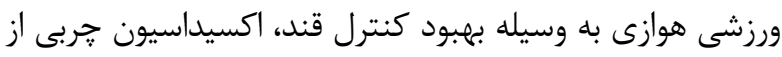

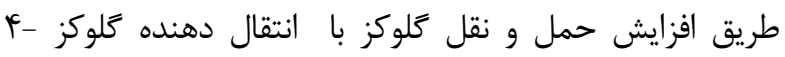
(Glucose transporter 4)

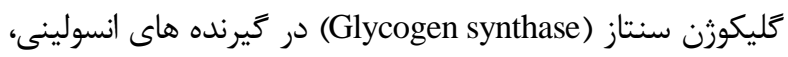
ذخيره كليكوزن در عضله و كبد، افزايش سنتز ترى كليسريد در

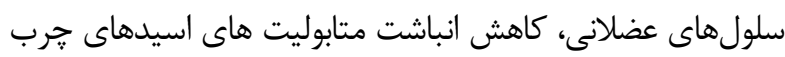

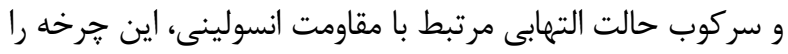

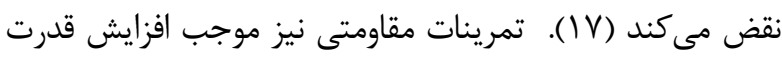

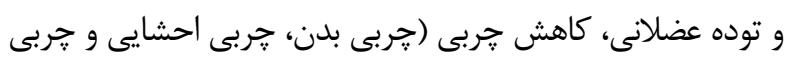

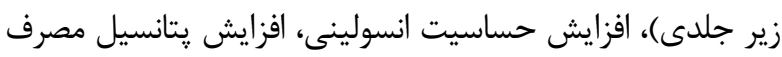

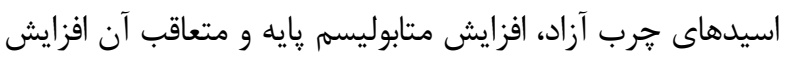

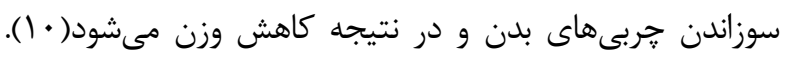
تمرينات تركيبى (هوازى و مقاومتى) نوع ديخرى از تمرينات است درن

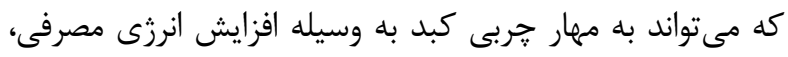

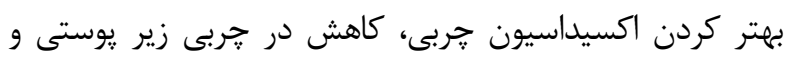

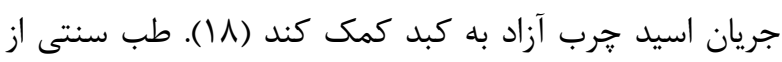

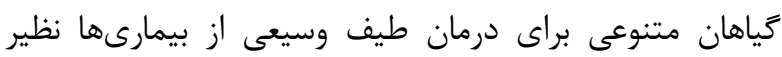
بيمارىهاى التهابى، ديابت و بسيارى از اختلالات كبدى و كليوى استفاده مى كند (9 1). از جمله اين كياهان، خرفه ( Oleracea است. خواص درمانى خرفه بسيار متعدد است كه (portulaca

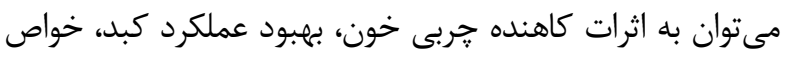

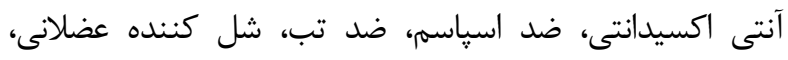
تقويت كننده سيستم ايمنى، تسكين عطش، قطع هر نوع خونريزى، خرد كردن سنگ مثانه، كاهش سرفه، سوزش مجراى

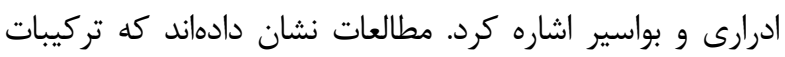

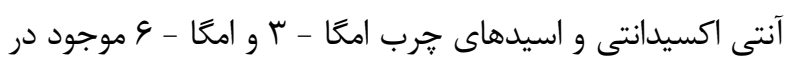
عصاره خرفه از طريق افزايش مصرف انرزى و كاهش بيان آنزيم-

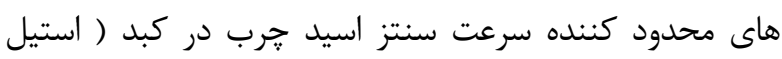
كوآنزيم آ كربوكسيلاز [ACC :Acetyl-CoA carboxylase] اسيد جرب سنتتاز [Fatty Acid Syntheses]) باعث مهار يراكسيداسيون ليييد مىشود. از سويى، خرفه حاوى مقادير زيادى آلكالوئيدهاى فنوليك است كه اين آلكالوئيدها نيز از طريق إيق افزايش اسيد جرب غيراشباع باعث مهار سنتز كلسترول مى إنوند (T·) آزمايشهاى متعدد نشان دادهاند كه خرفه موجب كاهش

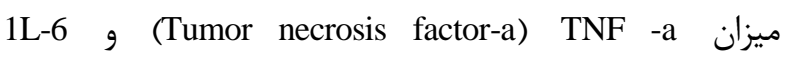
مىشود و از اين طريق موجب افزايش قدرت (Interleukin 6) 
بالاترين گريد (درجه جربى) كبد را داشتند، به قيد قرعه در يكىى

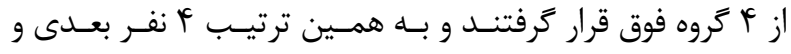

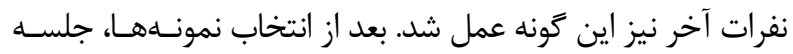
توجيهى با افراد واجد شرايط كذاشته شد و اطلاعات لازم بـهـ آنهـا در مورد اهـداف يـرّوهش، روش انجـام كـار، فعاليـتهــاى درنظــر كرفته شده در طول يزوهش، اسـتفاده از مكمـل زيـاهى، دفعـات

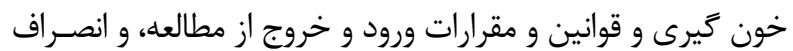
در صورت عدم رضايت داده شد و افراد شركت كننـده در مطالعـه، فرم رضايت كتبى آكاهانه در تحقيق را تكميل كردند.

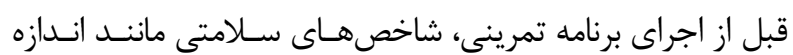
كيرى درصد جربى با استفاده از كـاليير و بـهـ روش سـه نقطـهاى جكسون -يولاك، نسبت دور كمر به باسن با استفاده از متر نـوارى

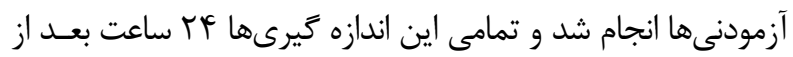

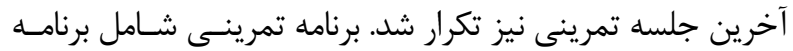

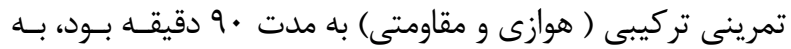

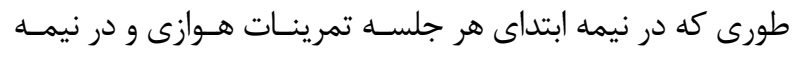

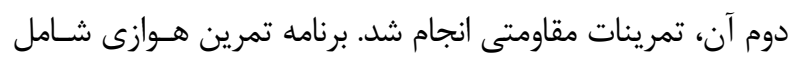

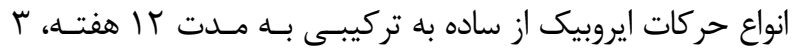

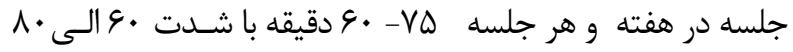
درصد حداكثر ضربان قلب بيشـينه محاسـبه شـد. اجـزاى برنامـهـ تمرين هوازى در هر جلسه شامل گرم كردن (• ( دقيقه راه رفتن،

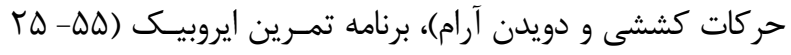

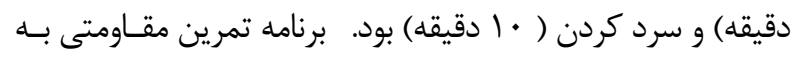

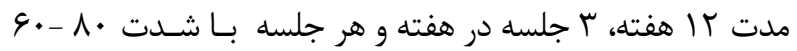

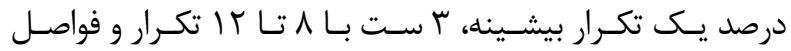

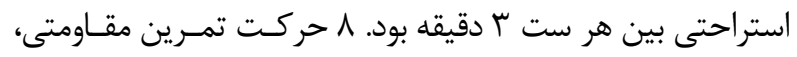

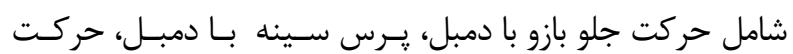

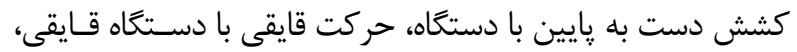

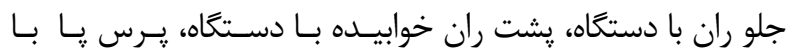

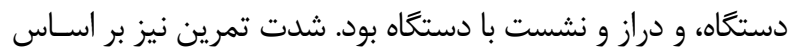
نسبتى از ضـربان قلـب بيشـينه محاسـبه و همجنــين بـه وسـيله

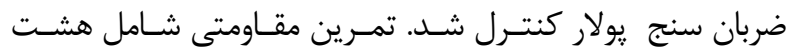

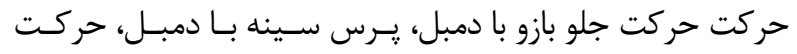

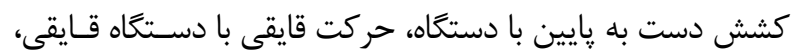

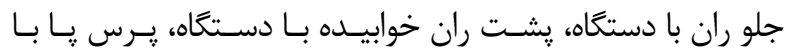
دستخاه، و دراز و نشست با دستگاه بود. در اين يزوهش از كيسول خرفه (يرويين آلا) استفاده شد. كيسـول

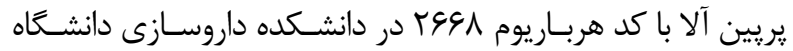
علوم يزشكى اصفهان، توسط شركت يـريّن اكسـير جهـانى ثبـت

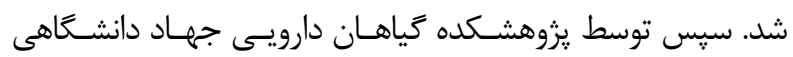

كاهنـده جربسى خــون اسـت، همجنــين بـر اسـاس بررسـىهـاى يزوهشگر به نظر مىرسد تاكنون يزوهشـى اثـر تعـاملى تمرينـات

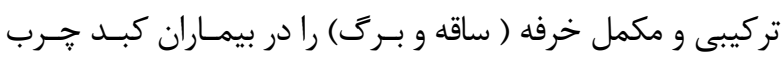
غيرالكلى مورد بررسى قرار نداده است. لذا در اين خصوص نياز بــهـ

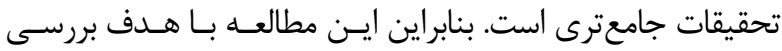

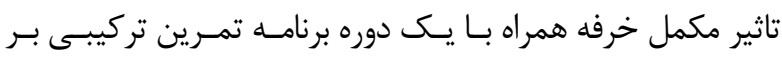

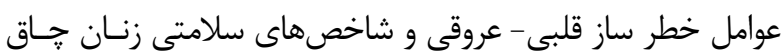

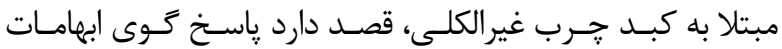
موجود در اين زمينه باشد.

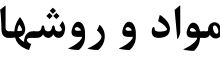

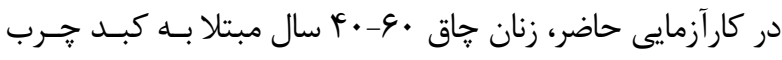

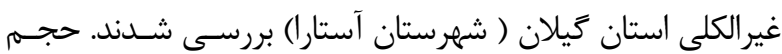
نمونه بر اساس فرمول تعيين حجم از طريق نرم افزار جى يـاور بـاــا .

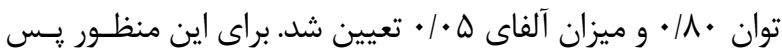

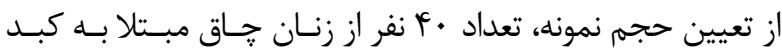
קرب غيرالكلى كه شرايط ورود به مطالعه را داشتند انتخــاب و بـهـ

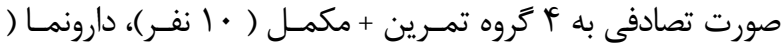

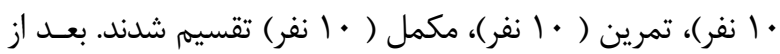
ثبت مشخصات فردى نمونهها در فـرم اطلاعـات فـردى، در مـورد

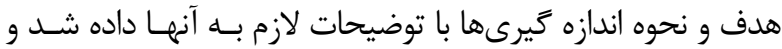

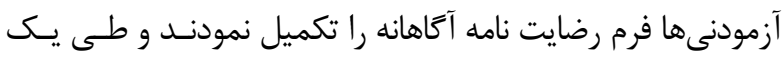
جلسه جداكانه، با تكنيكهــاى صـحيح تمرينـات و نحـوه مصـرف مكمل خرفه آشنا شدند. معيارهاى ورود به يـرّوهش، شـامل سـن .

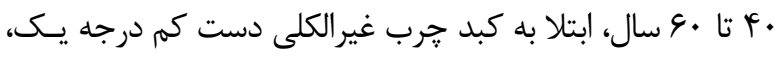

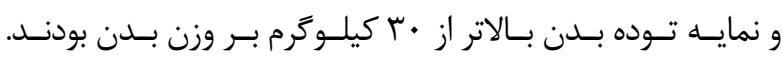

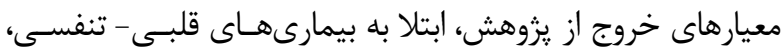

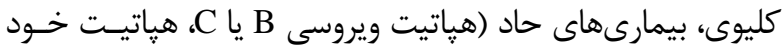
ايمنى، بيمارى سلياك، ويلسون، كمبـود 1 a 1 آنتـى ترييسـين و

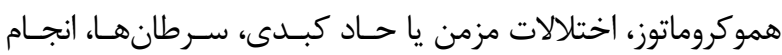
ييوند كبد)، بيمارى هيبوتيروئيدى، بيمارى فشار خون، اخـتلالات

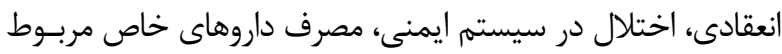

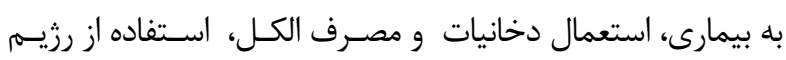
غذايى يا دارويى خاص، مصرف مكملها و گياهـان دارويسى، انجـام فعاليت منظم ورزشى ظرف 9 ماه كذشته، نداشتن منع شركت در

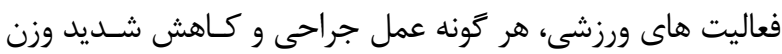

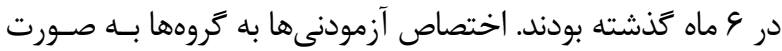
تصادفى (قرعه كشى) بود. نحوه تقسيم تصادفى بر مبنــاى همخَن

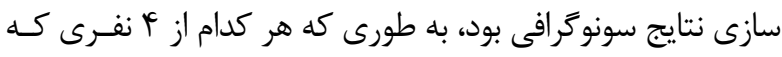




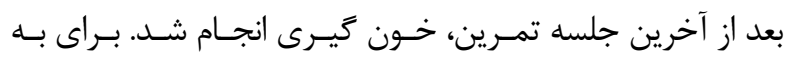

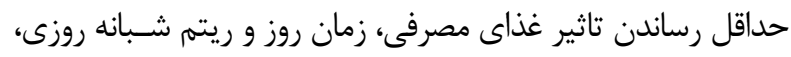

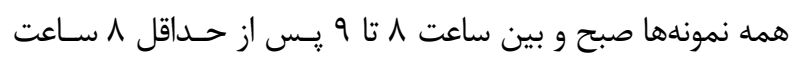

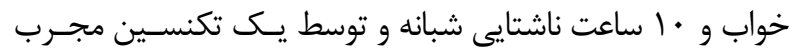

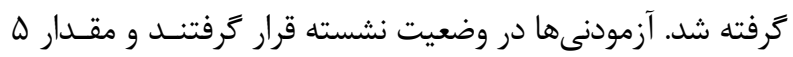
ميلى ليتر خون از سياهرى ناحيه سـاعد (آنتى كوبيتـال) كرفتـهـ

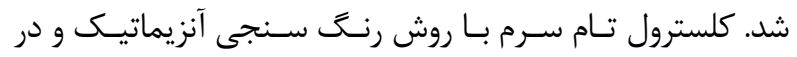

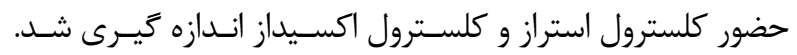

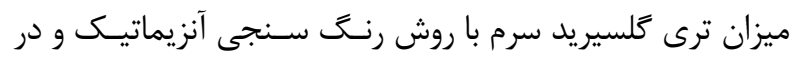

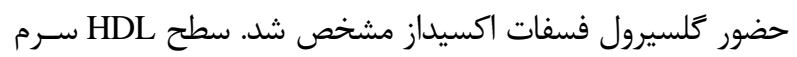
به روش آنزيمى پِ از رسوب بقيه لييويروتئين هاى حاوى آيو توسط محلول اسيد فسفوتنگستيك و كلريد منزيم تعيين شد.

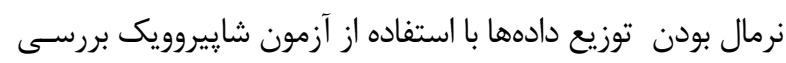

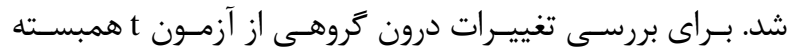

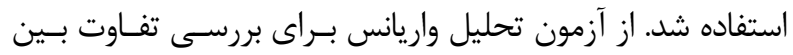

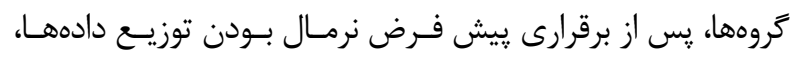

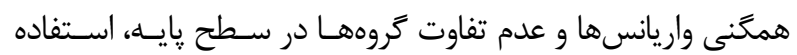

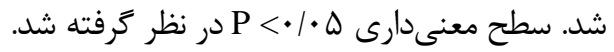

ملاحظات اخلاقى

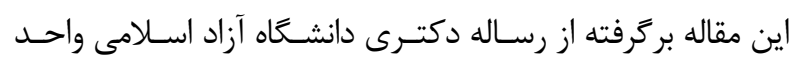

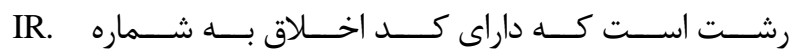
IAU.RASHT.REC. 1397. 034

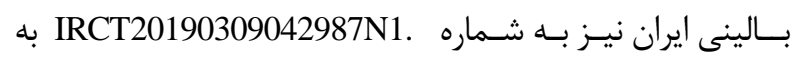
ثبت رسيده است.

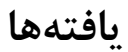

نتايج حاصل از بررسى نرمال بودن دادهها به كمك آزمون

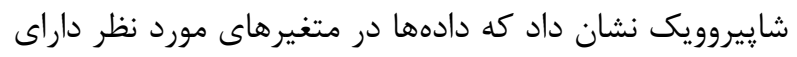

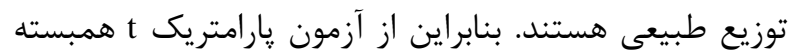

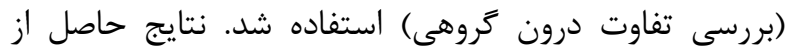

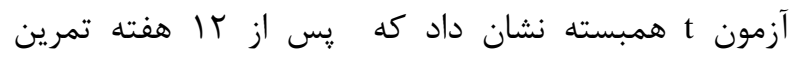

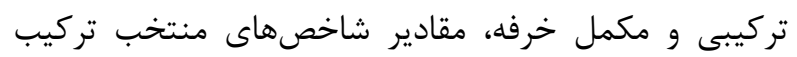

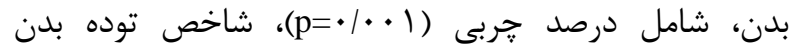

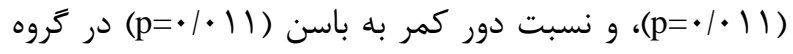

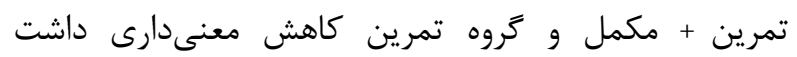

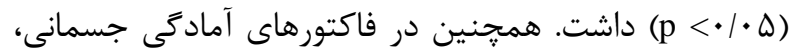

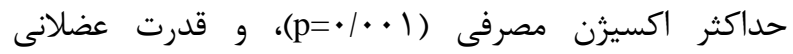

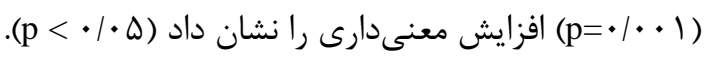

مورد تاييد قرار كرفت و يس از آن با شماره سـهـی به نـام آقـاى

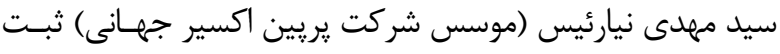

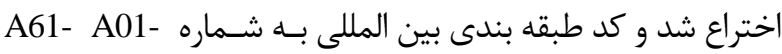

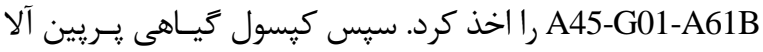

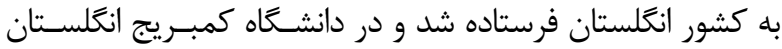

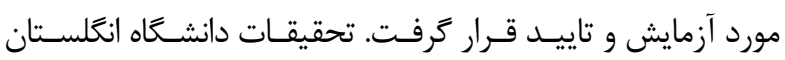
نشان داد كه تركيبات موجود در كيسول ير يرين آلا، مانع از انسـداد

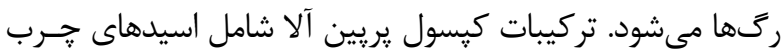

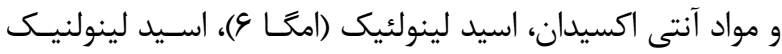

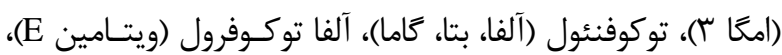

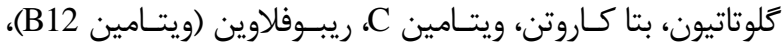

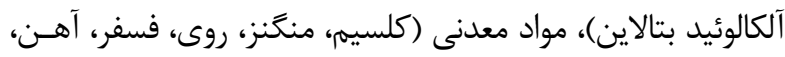

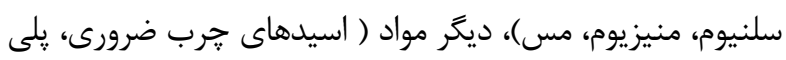

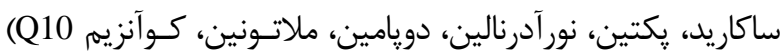

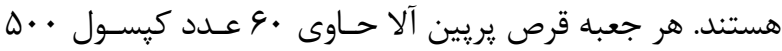

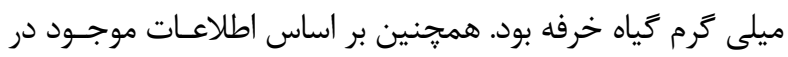

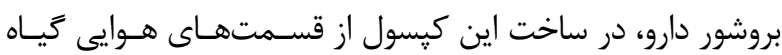
خرفه كه شامل برك، ساقه و دانه هـاى آن اسـت، اسـتفاده شـده

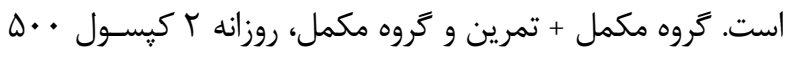

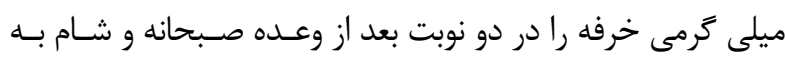
مدت كا هفته دريافت كردند. اين كيسول ساخت شركت سلامت

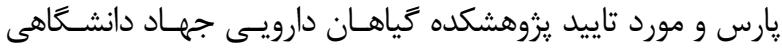

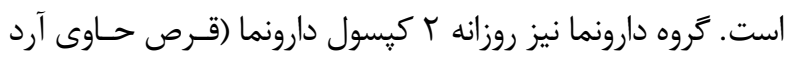
كَندم) دريافت كردند. جهت اطمينان از مصرف وعدهها، كيسولها

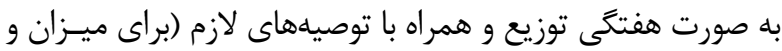

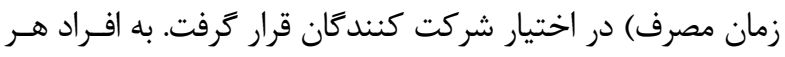

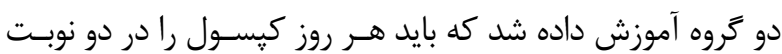

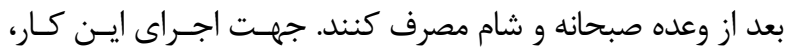

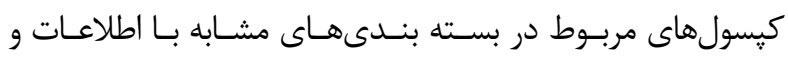

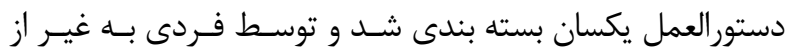

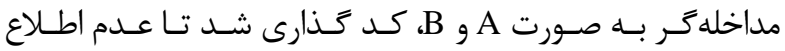

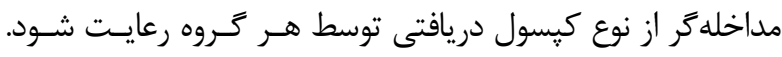

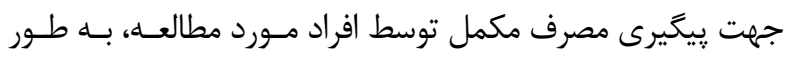

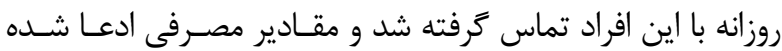
ييخيرى و اطلاعات لازم دريافت شد و آزمودنىهايى كه قرصهاى خود را مصرف نكرده بودند، از مطالعه كنار كذاشته شدند.

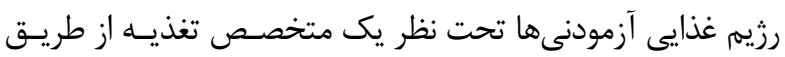

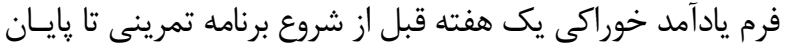

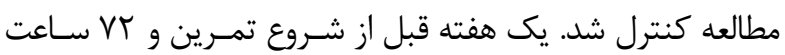




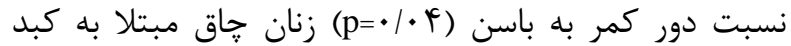

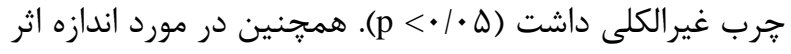

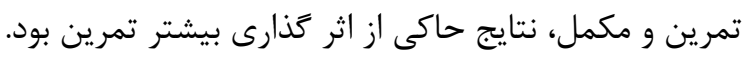

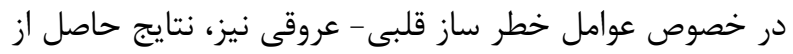

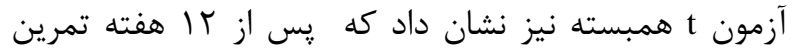

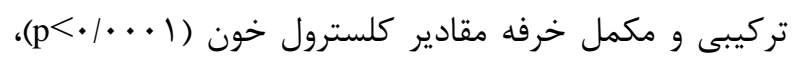

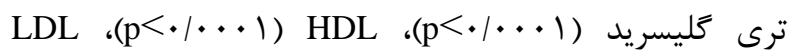

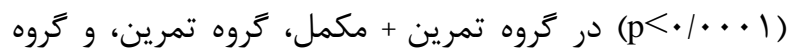
مكمل كاهش معنى دارى داشت.

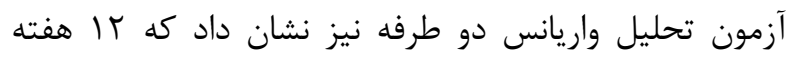
تمرين تركيبى اثر معنى دارى بر كاهش مقادير كلسترول خون

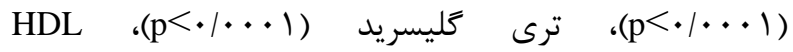

از آزمون تحليل واريانس دو طرفه براى تصميم كيرى جهت رد يا قبول اين فرضيه و همجنين بررسى تفاوت هاى بين

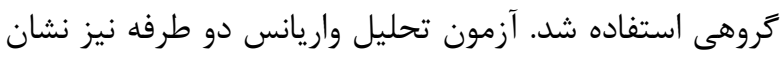
داد كه T| هفته تمرين تركيبى اثر معنى دارى بر كاهش نمايه

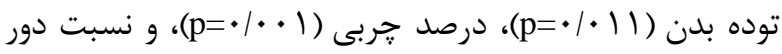

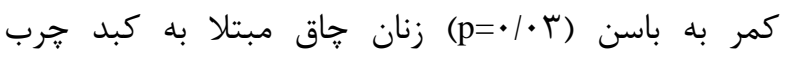

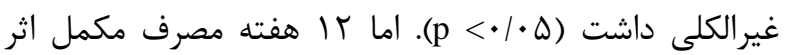

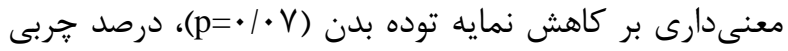

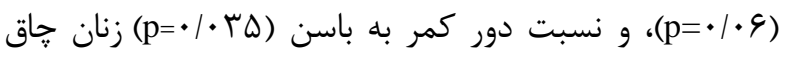

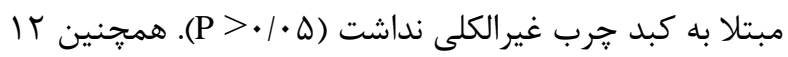

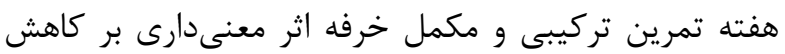

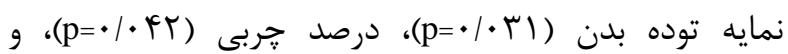

\begin{tabular}{|c|c|c|c|c|c|c|c|c|}
\hline \multicolumn{3}{|c|}{ تحليل واريانس دو طرفه } & \multirow{2}{*}{ انحراف مكمل } & \multirow{2}{*}{ انحراف土ميانغين } & \multirow{2}{*}{ انحراف土ميانكين } & \multirow{2}{*}{ انحر افرين+مكمل } & \multirow{2}{*}{ مرحله } & \multirow[t]{2}{*}{ متغيرها } \\
\hline $\mathrm{s} * \mathrm{t}$ & $\mathrm{s}$ & $\mathrm{t}$ & & & & & & \\
\hline *** & *** & 䄅米 & $r G 9 / 1 \pm r F / r \Lambda$ & $r \varepsilon \cdot / 9 \pm r / / / r$ & $r \& \Lambda / \Delta \pm r V / \& q$ & 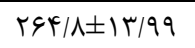 & ي بيش & كلسترول \\
\hline \multirow[t]{2}{*}{$\cdot 1 \cdot \cdot 1$} & $\cdot / \cdot r$ & $\cdot 1 \cdot \cdot 1$ & $r G F / \Lambda \pm r F / V \Lambda$ & $r \Delta V / \Delta \pm r \cdot / r \mid$ & $r \& N / \cdot \pm r V / q$. & $r \Delta q / r \pm 1 r / \varphi \varphi$ & 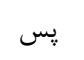 & (ميلى گرم/ دسى \\
\hline & & & $* \cdot / \cdot$ & $* \cdot / \cdot \cdot 1$ & $\cdot / \pi t$ & $* \cdot \cdot \cdot 1$ & $\mathrm{p}$ & ليتر) \\
\hline$* *$ & *** & $* *$ & $r r V / V \pm r \varepsilon / r q$ & $r r d / r \pm r G / r G$ & r & $r r q / r \pm r r / q q$ & ي بيش & ترى كليسريد \\
\hline \multirow[t]{2}{*}{$\cdot / \cdot r$} & $.1 \cdot$ & $\cdot 1 \cdot \cdot 1$ & $r r \Delta / \cdot \pm r \Delta / G Y$ & $r Y \Lambda / T \pm T G / G Y$ & $r \mu r / V \pm r r / V$. & 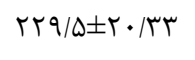 & 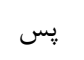 & (ميلى گرم/ دسى \\
\hline & & & $* \cdot / \cdot r$ & $* \cdot \cdot \cdot r$ & . pret & $* \cdot 1 \cdot \cdot 1$ & $\mathrm{p}$ & ليتر) \\
\hline *** & *** & $* *$ & $|F| q \pm 11 / 9$ & $\uparrow \& / r \pm V / \varepsilon q$ & $r q / q \pm r / r r$ & $F N / F r \pm I r / T \Delta$ & ي پيش & HDL \\
\hline \multirow[t]{2}{*}{$\cdot / \cdot$} & $\cdot 1 \cdot \cdot 1$ & $\cdot 1 \cdot r$ & $\{N / Y \pm \mid r / r \varepsilon$ & $\Delta \Delta / \Lambda V \pm \Lambda / r V$ & $r q / 1 \pm r / r$. & $\Delta 9 / F T \pm 1 \cdot / 99$ & 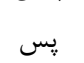 & (ميلى گرم/ دسى \\
\hline & & & $* \cdot 1 \cdot \uparrow$ & $* \cdot 1 \cdot \cdots 1$ & $\cdot / \pi \Delta$ & $* \cdot / \cdot r$ & $\mathrm{p}$ & ليتر) \\
\hline *** & $* *$ & *** & $\mid \wedge \Delta / 1 \cdot \pm r \Delta / \cdot \Lambda$ & $|\Lambda| / r \pm F \Delta / \Lambda$ & $|\wedge r| \cdot \pm r \Delta / V \mid$ & $|N N /| \cdot \pm F r /||$ & ي بيش & LDL \\
\hline \multirow[t]{2}{*}{$<\cdot \mid \cdots \cdot 1$} & $<\cdot \mid \cdots \cdot 1$ & $<\cdot \mid \cdots \cdot 1$ & $1 \Lambda r / \cdot \pm r r / q r$ & $|V V / G \pm F r / D|$ & $\mid \Lambda r / r T \pm F F / \cdot r$ & $|\vee q / \Delta \pm r \wedge /|$ & يس & (ميلى گرم/ دسى \\
\hline & & & $* \cdot 1 \cdot \cdot \Delta$ & $* \cdot / \cdot r$ & . Mr & $* \cdot / \cdot r$ & $\mathrm{p}$ & ليتر) \\
\hline
\end{tabular}

\begin{tabular}{|c|c|c|c|c|c|c|c|c|}
\hline \multicolumn{3}{|c|}{ تحليل واريانس دو طرفه } & \multirow{2}{*}{ انحراف مكمل } & \multirow{2}{*}{ انحراف تمرين } & \multirow{2}{*}{ انحراف土 ميانغين } & \multirow{2}{*}{ انحر افين+مكمل } & \multirow{2}{*}{ مرحله } & \multirow[t]{2}{*}{ متغيرها } \\
\hline $\mathrm{s} * \mathrm{t}$ & s & $\mathrm{t}$ & & & & & & \\
\hline *** & $\cdot / \cdot \Delta 9$ & $* *$ & $r Y / r \pm V F / / F$ & $r 1 / r \pm F r / \cdot r$ & $r T / T \pm 99 / \cdot \Delta$ & $r \cdot / r \pm q / 99$ & ييش & نمايه توده بدن \\
\hline$\cdot|\cdot r|$ & &.$/ \cdot 11$ & $\begin{array}{c}r T / r \pm N / T \Delta \\
\cdot / r T .\end{array}$ & $\begin{array}{c}r \cdot / r \pm \Delta \Delta / \vee q \\
* \cdot / \cdot 1\end{array}$ & $\begin{array}{c}r T / T \pm V / I V \\
\cdot / r \cdot r\end{array}$ & $\begin{array}{c}r q / r \pm q / r r \\
* \cdot \cdots l\end{array}$ & يس & (كيلو زرم/مترمربع) \\
\hline *** & .1 .9 & 米䊅 & $r q / r \pm \Delta / \Delta r$ & $r \Delta / r \pm F / r$. & $r V / r \pm \cdot r / \varphi$. & rr/VIF/TG & ي ي & درصد جربى \\
\hline.$/ . F T$ & & $\cdot 1 \cdot \cdot 1$ & $\begin{array}{c}r \varepsilon / r \pm V / V r \\
\cdot / \cdot \varphi\end{array}$ & $\begin{array}{l}r / r \pm 19 / 9 \vee \\
*</ \cdots 1\end{array}$ & $\begin{array}{c}r V / r \pm . q / 9 q \\
\cdot / \cdot \Delta 1\end{array}$ & $\begin{array}{l}r r / r \pm 19 / 9 \Lambda \\
*<\cdot \cdots \cdot 1\end{array}$ & يس & \\
\hline$* *$ & $\cdot / r \Delta$ & $* *$ & $\cdot / 9 \mu \pm \cdot / \cdot 1$ & $\cdot / 9 f \pm \cdot / \cdot r$ & $\cdot / 99 \pm \cdot / \cdot \Delta$ & $\cdot / 9 r \pm \cdot / \cdot r$ & ي تيش & نسبت دور كمر به لكَن \\
\hline $.1 \cdot 4$ & & $\cdot / \cdot r$ & $\begin{array}{c}\cdot / q 4 \pm \cdot / \cdot \cdot \\
\cdot / 4 \Lambda\end{array}$ & $\begin{array}{c}\cdot / 9 \cdot \pm \cdot / \cdot 1 \\
* \cdot 1 \cdot \cdot 1\end{array}$ & $\begin{array}{c}.199 \pm \cdot 1.9 \\
.109\end{array}$ & $\begin{array}{c}\cdot \mid \wedge \vee \pm \cdot / \cdot \vee \\
* \cdot / \cdot \cdot \mid\end{array}$ & يس & \\
\hline
\end{tabular}

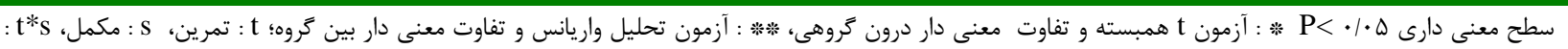


خرفه را بر روى انسانها بررسى كردهاند. برخى از مطالعات، اثر

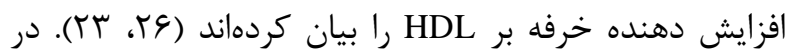

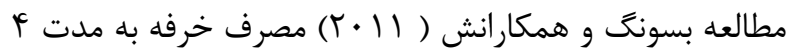

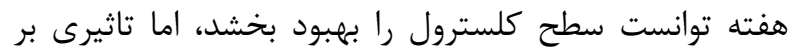

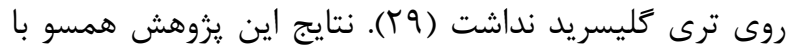

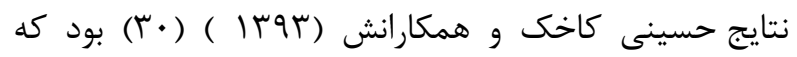
نشان دادند هشت هفته رزيم غذايى به تنهايى و تمرين در

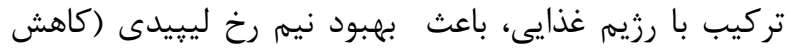

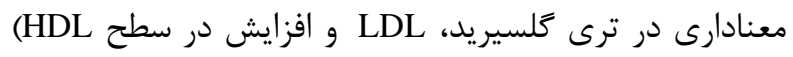

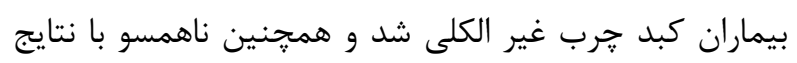

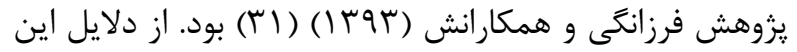

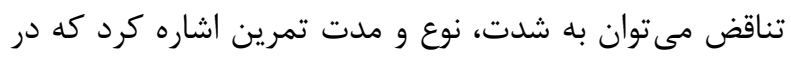

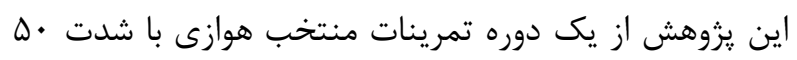
تا ه\&٪ حداكثر ضربان قلب، به مدت هأ تا •ع دقيقه، جلسه در هفته براى مدت و هفته استفاده كرده بود كه تفاوت

معنى دارى در يروفايل ليييدى را مشاهده نكرد ( آ⿱艹).

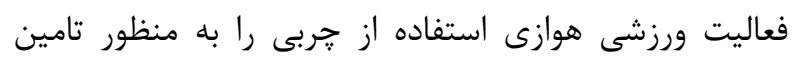
سوخت هنكام فعاليت ورزشى افزايش مى دهد. با وجود اين، افزايش در اكسايش خربى به دسترسى بيشتر به اسيدهاى

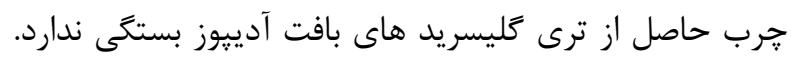

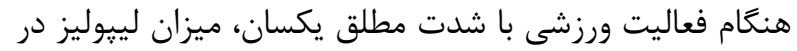
ورزشكاران تمرين كرده استقامتى و داوطلبان تمرين نكرده

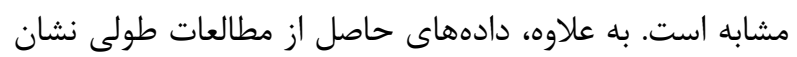

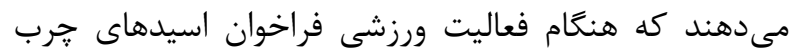
يلاسمايى افزايش نمى يابد و حتى ممكن است يس إن از هفتهائ

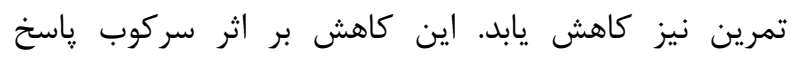

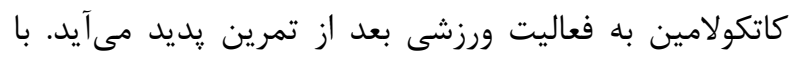
اين وجود، حتى زمانى كه ياسخ كاتكولامينى كمتر نباشد،

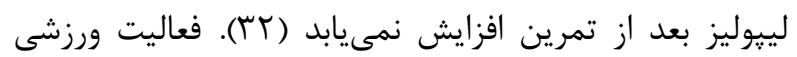

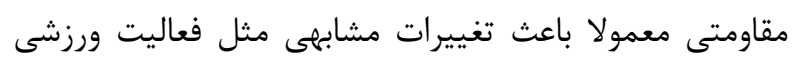

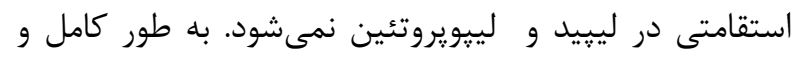
دقيق نمىدانيم ترا تغييرات توام با اين تمرين كم است، ولى

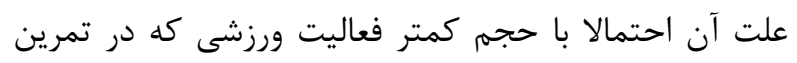
مقاومتى انجام مىشود، ارتباط دارد. تمرين مقاومتى، مقادير ترى كليسريد خون را حتى هنكامى كه مقادير اوليه آن ها زياد

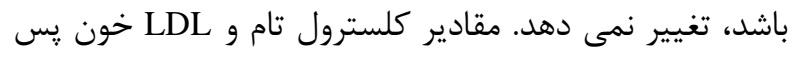

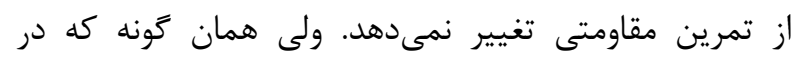
تمرين استقامتى نيز كفتيم مقادير مقادير كلسترول تام و

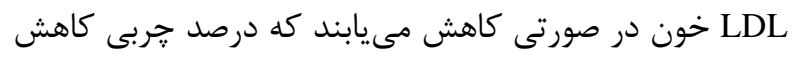

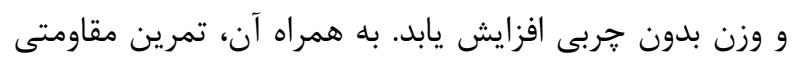

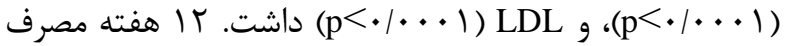
مكمل اثر معنى دارى بر كاهش مقادير كلسترول خون HDL ان

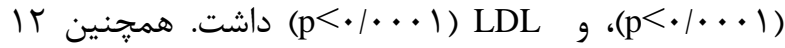
هفته تمرين تركيبى و مكمل خرفه اثر معنىدارى بر كاهش

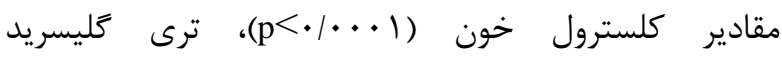
$(\mathrm{p}<\bullet / \cdots 1)$ LDL,$(\mathrm{p}<\bullet / \cdots 1)$ HDL $،(\mathrm{p}<\bullet / \cdots 1)$ داشت. همجنين در مورد اندازه اثر تمرين و مكمل، نتايج

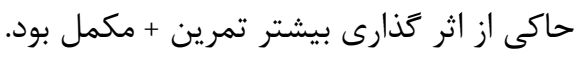

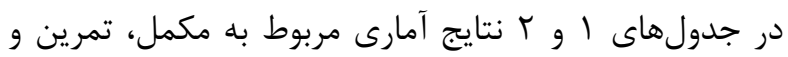
استفاده همزمان مكمل و تمرين آمده است.

\section{بحث}

نتايج يزوهش حاضر نشان داد كه | ب هفته تمرينات تركيبى و

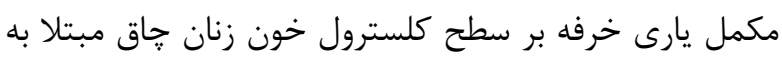

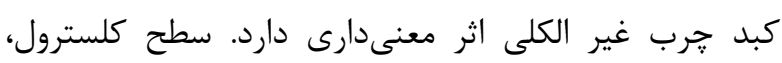
LDL و وترى كلسيريد در گروههاى تمرين + مكمل، گَروه تمرين، كروه مكمل كاهش معنى دار و سطح HDL

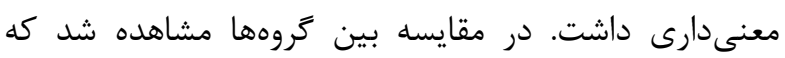
تفاوت معنى دارى بين كروههاى تمرين + مكمل با بارئ ساير كروهها وجود داشت (ه•/

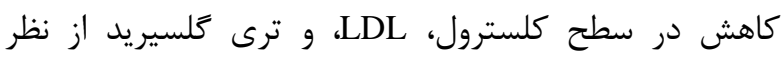
آمارى تغييرات معنى دارى مشاهده نشد (ه • • • (p).

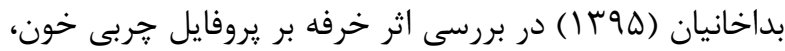

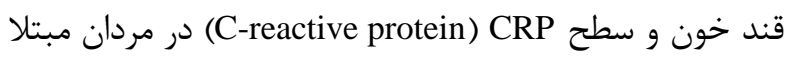
به سندروم متابوليك به اين نتيجه رسيدند كه م هفته تمرين

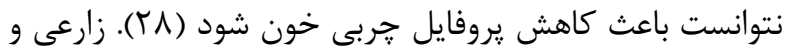

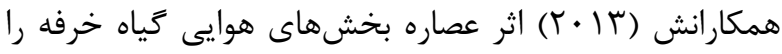

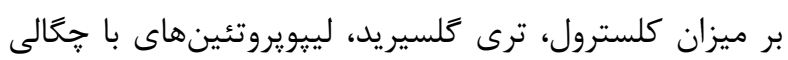

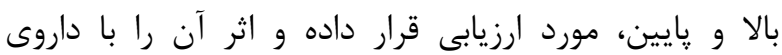
خوراكى آتورواستاتين مقايسه كردند. نتايج اين يزورهش نشان فران

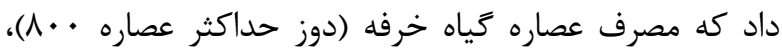

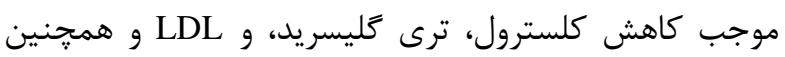
باعث افزايش HDL شد (•r). كاهش كلسترول، LDL و ترى

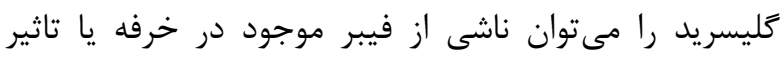

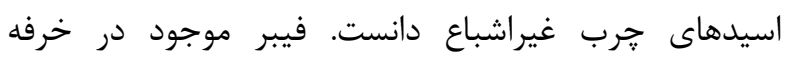
احتمالا با اتصال به كلسترول موجود در رزيم غذايى از جذب إنب

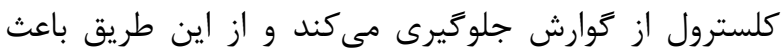

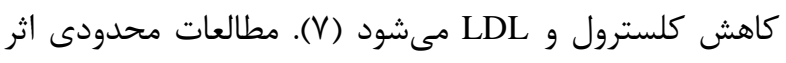


براى معكوس كردن انتقال كلسترول :ذيرفته مىشوند. آنزيم

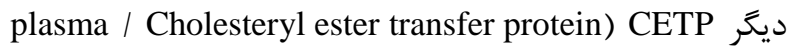
است كه ظاهرا بعد از تمرين ورزشى (lipid transfer protein كاهش مى يابد و ممكن است نقشى در درست شدن HDL بازى كند. CETP برداشت كلسترول استريفه را از HDL به ذرات بزرگتر غنى از ترى كليسريد (مانند VLDL) كاتاليز

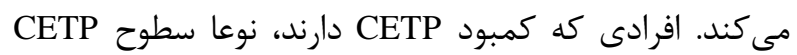

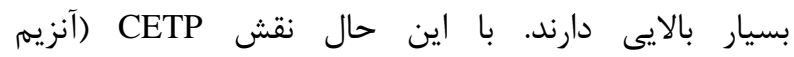
لييويروتئين ليياز) يس از تمرين ورزشى كاملا روشن نيست. ممكن است به يايين آوردن مقدار LETP كه با توليد رسوب در ديواره شريان ارتباط دارد، هم كمك لـ

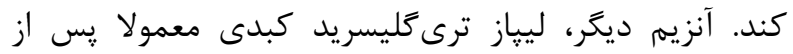

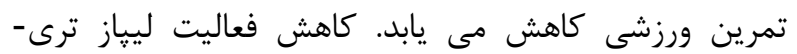
كليسريد كبدى با كاهش كاتابوليسم HDL در كبد، نيمه عمر را در گردش خون طولانى مى كند. افزايش نيمه عمر HDL متابوليك HDL احتمالا به افزايش زير شاخه

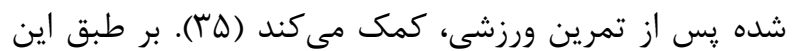
يزوهش، تغيير معنى دار در سطوح HDL بعد از تمرينات

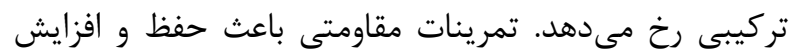

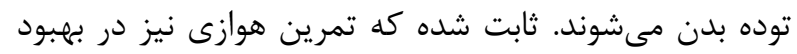
HDL يروفايل جربى موثر است. كاهش ترى تليسريد و افزايش هر دو يس از تمرين استقامتى ديده شده است. در مقابل، تمرين مقاومتى ممكن است به اين اندازه، موثر نباشد. اطلاعات مقطعى نشان ميدهند كه ورزشكاران ورزيده معنى مقاومتى، يروفايل جربى خونى همانند همتايان بى تحرك خود دارند. افزايش استفاده از جربىهاى خون حيى حين فعاليت هوازى،

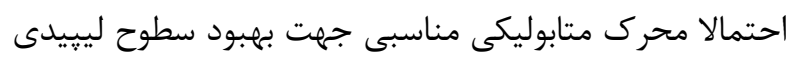
خون است. ملاحظه مهم ديكر آن است كه كاهش وزن كه

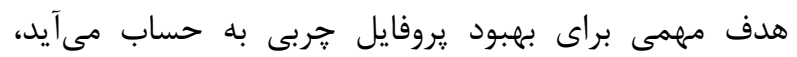

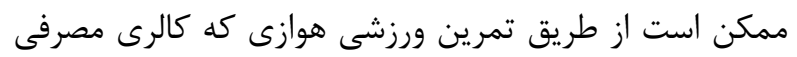
بيشترى لازم دارد، بهتر حاصل شود. با وجود اين، تمرين مقاومتى بايد به عنوان شيوهاى فرعى و مهلم براى هر برنامه

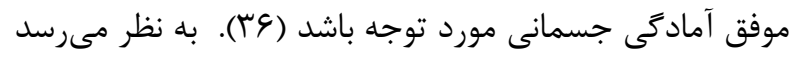

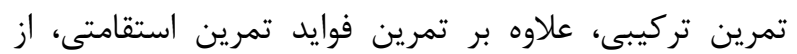
مزيت هاى تمرين مقاومتى نيز بهرهمند است. از طرف ديگر عصاره خرفه حاوى مقادير زيادى آلكالوئيدهاى فنوليك است كه اين آلكالوئيدها سبب مهار سنتز مهرو كلسترول مىشوند. به علاوه، در خرفه مقادير زيادى تركيبات آنتى اكسيدانى و جربى هاى امغا- ب و امظا -4 وجود دارد كه سبب مهار :يراكسيداسيون ليييدى مىشود. در مطالعات آمده
نيز انجام گيرد. در صورتى كه كل وزن بدن، وزن بدون جربى بدن و درصد جربى تغيير نكند، كلسترول و LDL نيز تغيير نمى كنند. يس از تمرين مقاومتى، تغييرى در

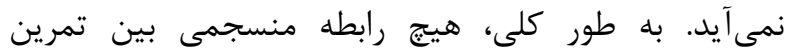
مقاومتى و تغييرات كلسترول و ليبويروتئين وجود ندارد. هر بر بـئين ״ند تمرين مقاومتى بر كلسترول خون و رابطه كلسترول با

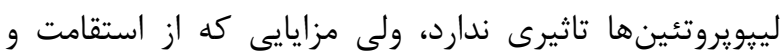

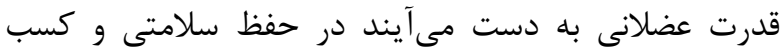
آمادگى عمومى مهماند (rT). از طرفى در مطالعهاى گزارش

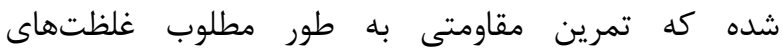
لييويروتئين با جگالى يايين را كاهش و ليبيويروتئين با جَالى بالا را افزايش مى دهد. به هر حال نتايج متضادى هم در اين ين بين

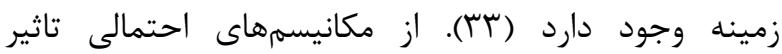
فعاليتهاى هوازى بر كاهش كلسترول خون، در تحقيقات مختلف به وفور يافت شده و يك نتيجه كلى از تمامى تحقيقات انجام شده در اين زمينه، اكسيداسيون جربى در در اثر افزايش فعاليت بدنى در ورزشهاى هوازى بيشترين بازدهى را داشته كه اين اكسيداسيون جربى مىتواند باعث كاهش تودههاى جربى ساير اعضاى بدن و همين طور كاهش

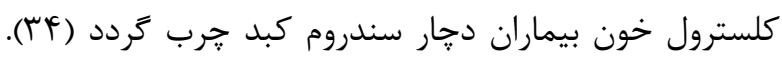
از مكانيسمهاى تاثير تمرينات ورزشى هوازى بر ترى نيز مىتوان به اكسيداسيون جربى اشاره كرد. در هنگام فعاليت ورزشى با افزايش فعاليت سمياتيكى، آزادسازى لهى

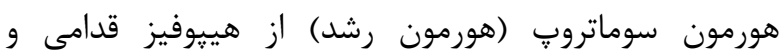
همجنين هورمون كورتيزول از قشر فوق كليوى همزمان

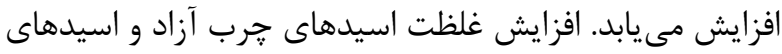
آمينه در خون كه با افزايش هورمون رشد و كورتيزول همراه است، سوبستراى لازم را براى عمل كلوكونئوزنز و سوختهاى جايگزين را براى متابوليسم انرزى عضله اسكلاى (اسيدهاى

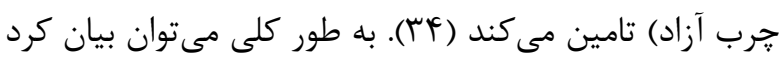

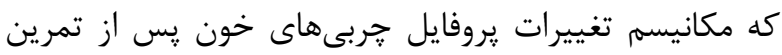
ورزشى به طور كامل معلوم نشده است، اگرجه بسيارى از ييشرفتها ممكن است به تغييرات آنزيمى نسبت داده شود.

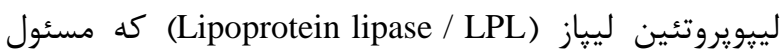
هيدروليز ذرات غنى از ترى لمليسريد مانند VLDL و شيلوميكرونها است، يس از يك جلسه تمرين و ورزش افزايش مىيابد. LPL افزايش يافته به طور مستقيم با رايين آوردن سطحوح ترى كليسريد پِلاسما مرتبط است. پس از هيدروليز ليييد، ذرات باقيمانده ممكن است به HDL در حال شكل گيرى، منتقل شوند و يا به وسيله HDL عردش خرش خون، 
همكارانش (بوج|) در بررسى اثر برنامه تمرينى تركيبى

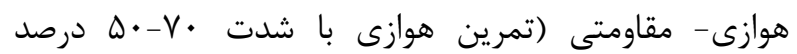

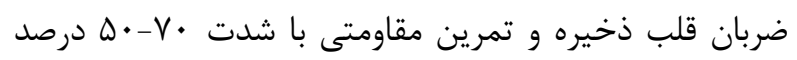

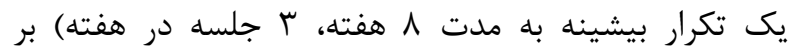

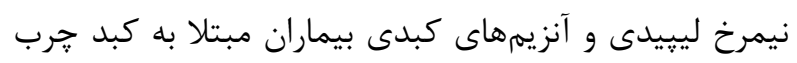

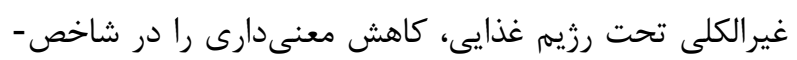

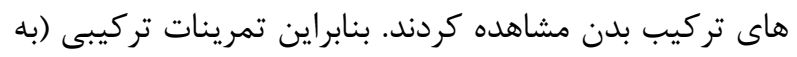

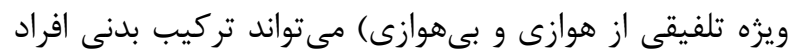
را كاهش داده و كارايى سيستم قلبى - عروقى آنها را افزايش

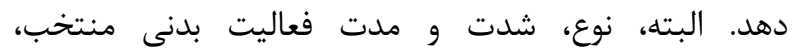
متغيرهاى مهمى هستند كه مىتوانند در نوع اثركذارى فعاليت بدنى بر روى شاخصها دخالت كنند (•) (F). لى و همكارانش

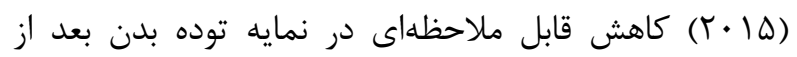
انجام تمرين مقاومتى كزارش كردند (•) (1). تذهيبى و

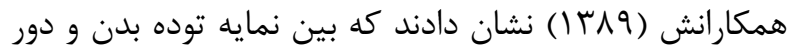

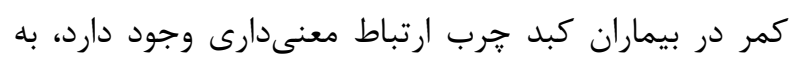

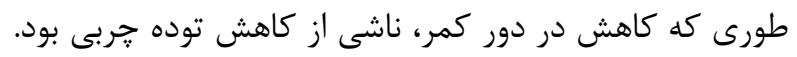

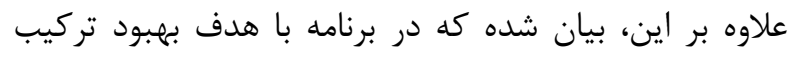

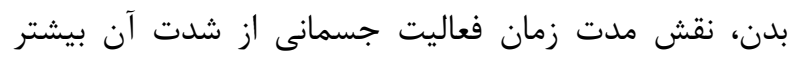

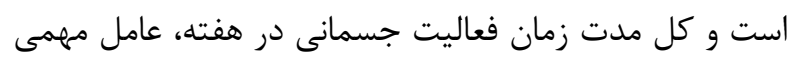

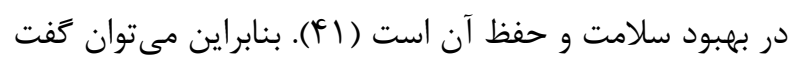

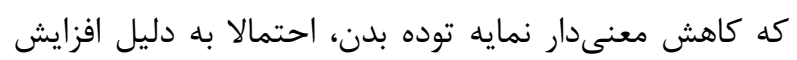

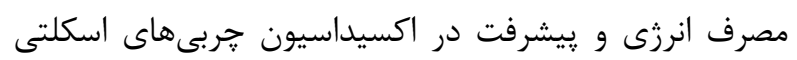

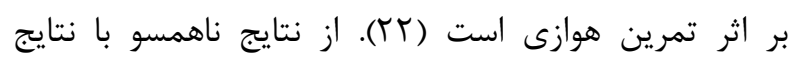

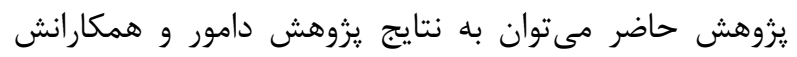
(T-1Y)

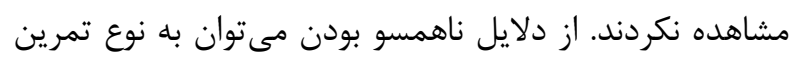

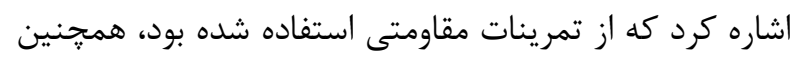

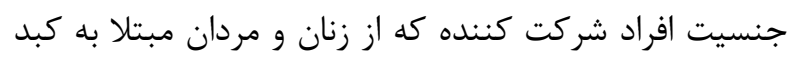

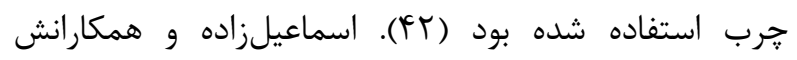

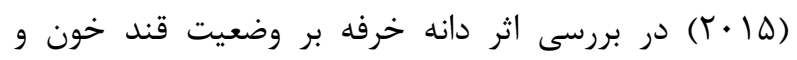

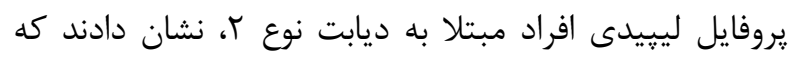

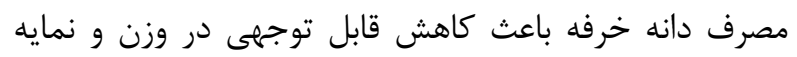

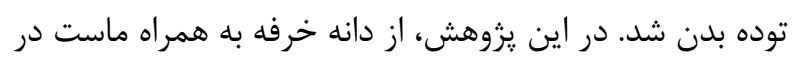

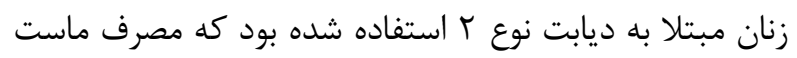

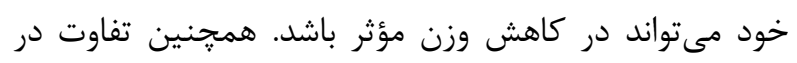

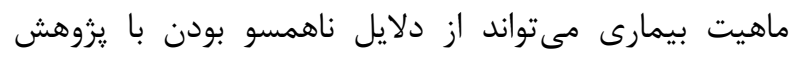

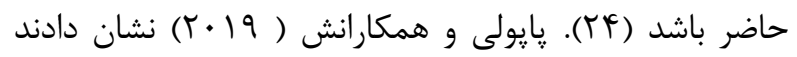

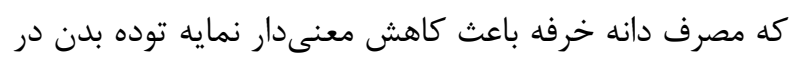

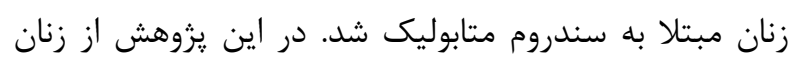

است يلى فنلها و اسيدهاى جرب امخا-ب موجود در خرفه،

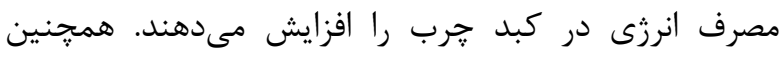
عصاره خرفه مىتواند بيان استيل كوآنزيم A A Fatty Acid ) FAS و (Acetyl-CoA carboxylase: ACC) Syntheses جرب در كبد و بيان يروتئين متصل شونده به عنصر تنظيم كنيم كننده استرول (Sterol regulatory element-binding ا كه بيان اين آنزيمهاى محدود (protein: SREBP-1C

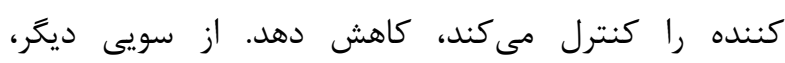

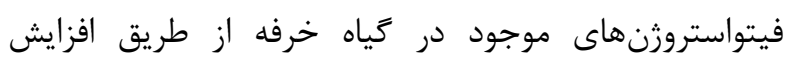

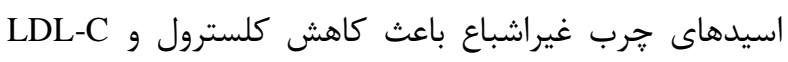

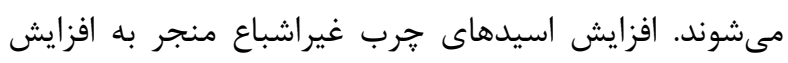

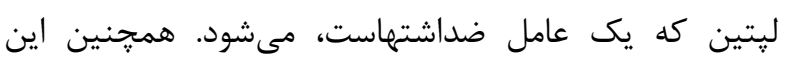

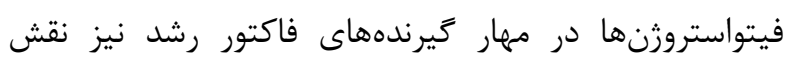

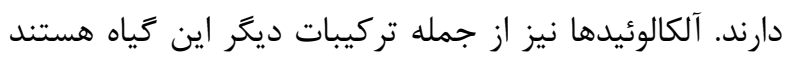

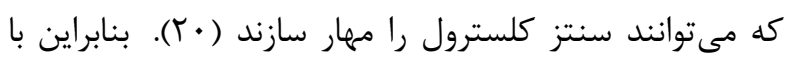

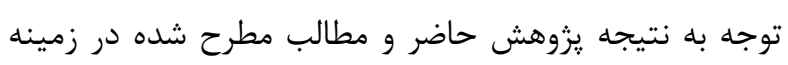

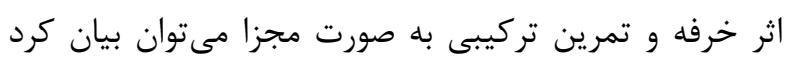

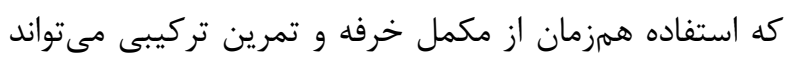

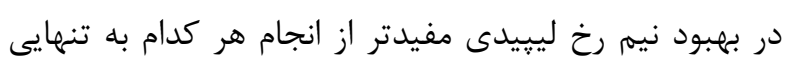
باشد. نتايج آزمون تحليل واريانس دو طرفه نشان داد كه با بان هفته

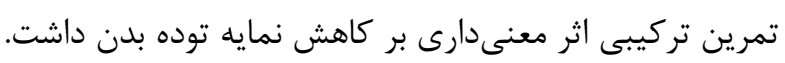

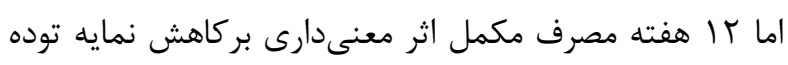

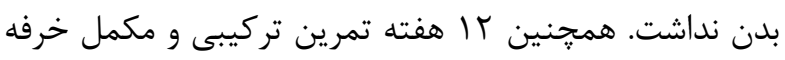

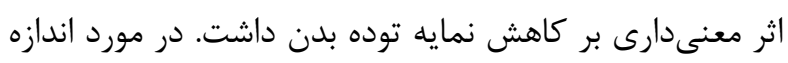

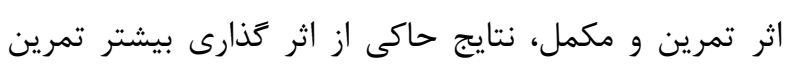

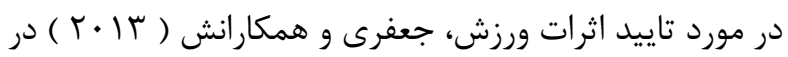
بررسى اثر تمرين هوازى (با شدت

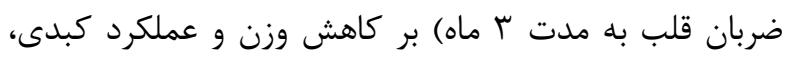

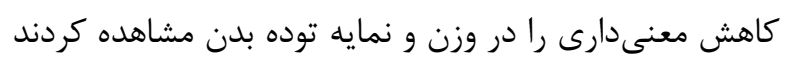

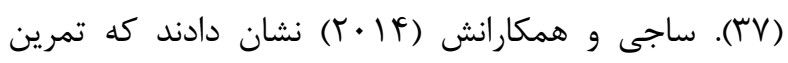

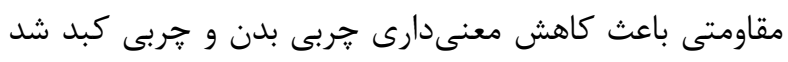

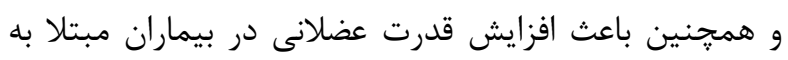

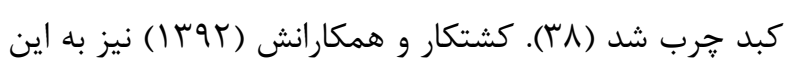

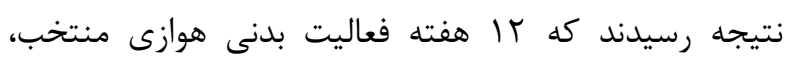

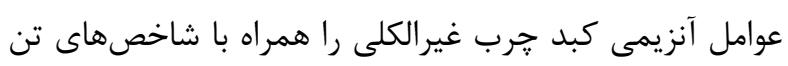

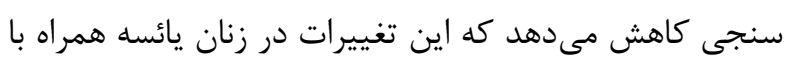

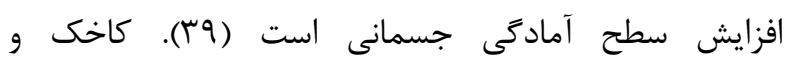


توجه به اينكه درصد جربى به معناى درصد جربى موجود در اندامهاى احشايى بدن (بيشترين نقاط تجمع جربى در بدن

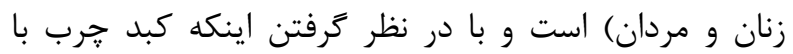
افزايش تجمع جربى احشايى (از طريق افزايش رها شدن

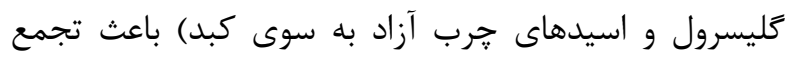
خربى در كبد و ايجاد التهاب و فيبروز كبد (لهأ) همراه است،

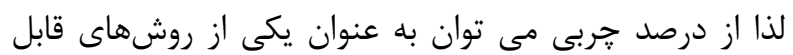
اجرا براى ارزيابى و تشخيص بيمارى كبد جرب استفاده كرد

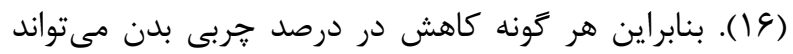
عامل كليدى در كاهش وزن، كاهش جربى كبد و در نهايت بهبود كبد جرب باشد. در يزوهش حاضر و در تاييد اثرات ورزش، كاهش در وزن و درصد جربى مىتواند نشان دهنده

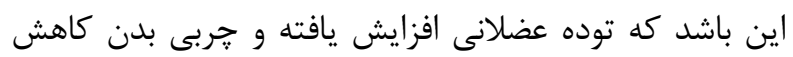

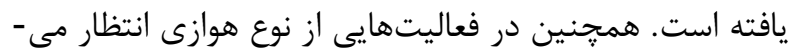
رود كه حين فعاليت مذكور، اسيدهاى جرب به عنوان سوخت

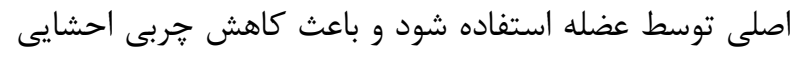

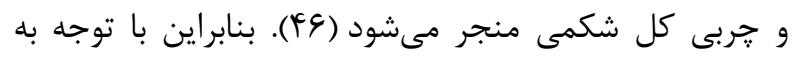
ماهيت يزوهش كه تمرين از نوع تركيبى هوازى و مقاومتى

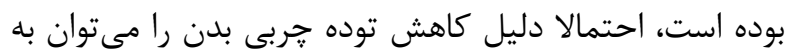
انجام تمرينات هوازى نسبت داد. نتايج تحليل واريانس دو طرفه نشان داد كه باهفته تمرين تركيبى اثر معنىدارى بر كاهش نسبت دور كمر به باسن داشت. r ا اهفته مصرف مكمل اثر معنى دارى بر كاهش نسبت دور كمر به باسن نداشت. \ا هفته تمرين تركيبى و مكمل خرفه اثر معنى دارى بر كاهش نسبت دور كمر به باسن داشت.

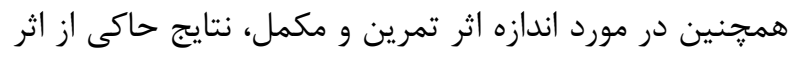

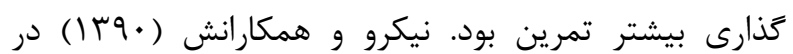

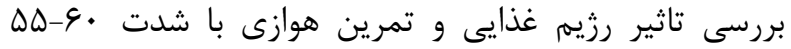
درصد ضربان قلب ذخيره بر سطوح آمينوترانسفرازهاى سرم بيماران استئاتوهياتيت غيرالكلى، كاهش معنى دئى دارى بر نسبت دور كمر به باسن، نمايه توده بدن و وزن مشاهده كردند (9).

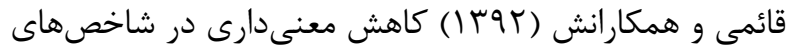
تن سنجى وزن، نمايه توده بدن، و دور كمر مشاهده كردند

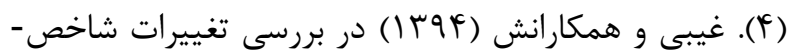
هاى بافتى، سرمى كبد و سندروم متابوليك در بيماران مبتلا

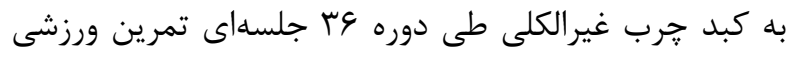

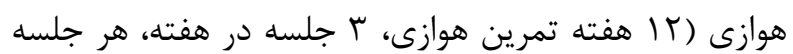

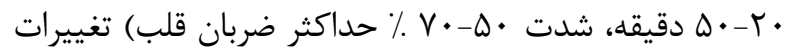

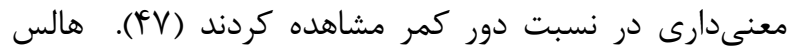

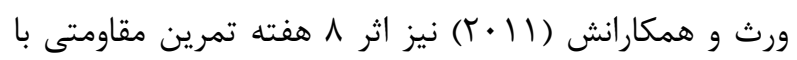

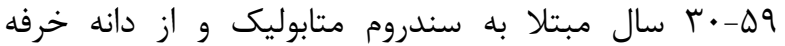
استفاده شده بود. جنسيت افراد و نوع بيمارى و استفاده از دانه خرفه مى تواند از دلايل ناهمسو بودن با نتايج يزوهش حاضر بوري باشد (YV). كتب و همكارانش (I (Y) به دنبال مصرف خرفه، كاهش معنىدارى در نمايه توده بدن در بيماران مبتلا به

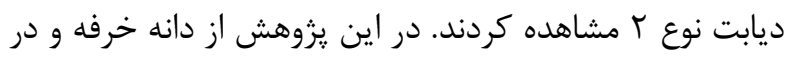

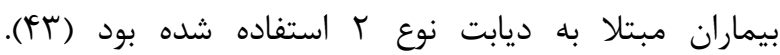

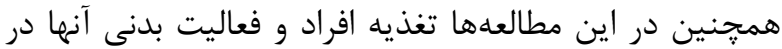
ابتدا و انتهاى مطالعه بررسى نشده بود كه مىتواند از ديخر دلايل تناقض با نتايج يزوهش حاضر باشد. نتايج تحليل واريانس دو طرفه نشان داد كه با بادئ هفته تمرين تركيبى اثر معنى دارى بر كاهش درصد جربى داشت. اما

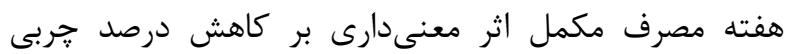
نداشت. همجنين T/ هفته تمرين تركيبى و مكمل خرفه اثر معنىدارى بر كاهش درصد جربى داشت. در مورد اندازه اثر تمرين و مكمل، نتايج حاكى از اثر گذارى بيشتر تمرين بود.

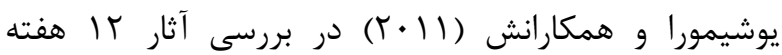
تمرين هوازى تداومى ( •."r دقيقه دويدن در هفته تا آستانه

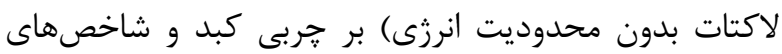
عملكرد كبد (AST)، و (ALT) مقاومت انسولين، كاهش معنى دارى در جربى بدن، جربى احشايى و زير يوستى را نشان

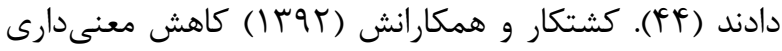
در جربى بدن در اثر آ هفته تمرينات منتخب (برنامه

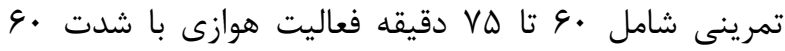
درصد) بر عوامل آنزيمى كبد جرب غيرالكلى در زنان يائسه مشاهده كردند كه اين تغييرات در زنان يائسه همراه با افزايش

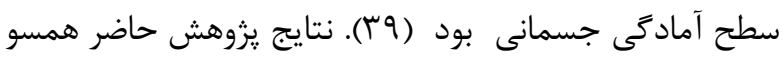

با نتايج يزوهش قربانيان بود (\&\&).

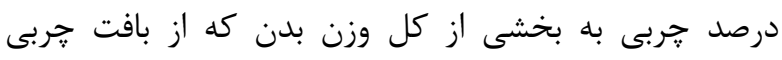

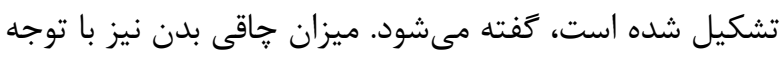
به همين شاخص ارزيابى مىشود. با توجه به خطرهاى تندرستى (ديابت نوع r، بيمارى كرونرى قلب، بيمارى اختلال

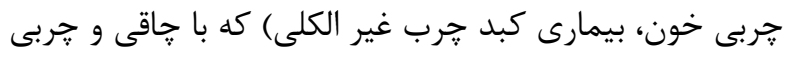
اضافى بدن همراه است، تعيين درصد جربى بدن، مهرمترين معيار است. از نظر تندرستى، حد معيار جربى بدن كه شخص را در معرض خطر بيمارى قرار مىدهد، براى مردان مساوى يا

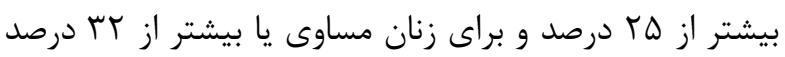
است. همجنين توصيه شده است كه درصد جربى بدن مردان

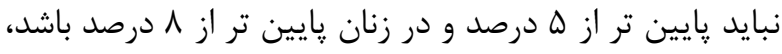

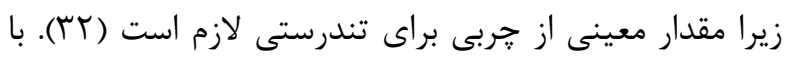


ديابتى استفاده شده بود كه مصرف ماست خود مىتواند يكى

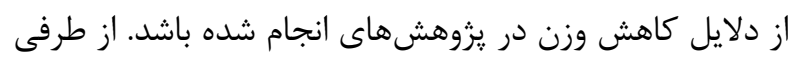

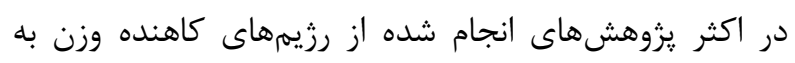

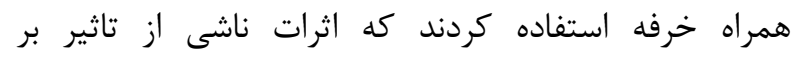

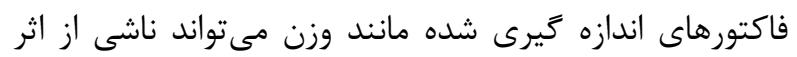

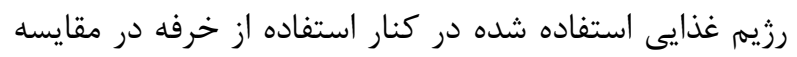

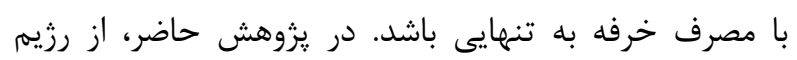

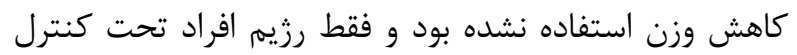

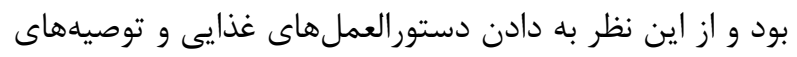
غذايى و بايدها و نبايدهاى مصرفى در بيماران مبتلا به كبد ايد ديد

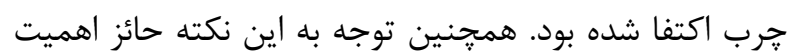

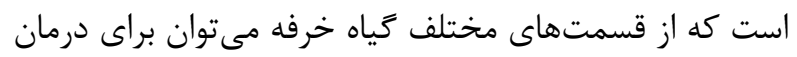

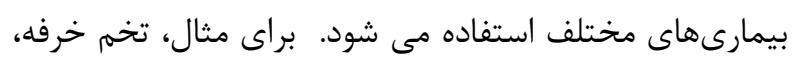

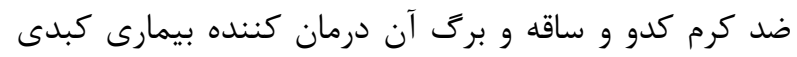

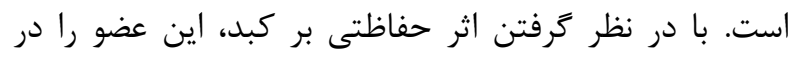

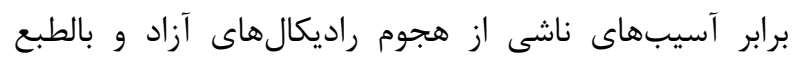

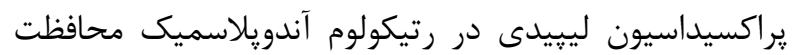
مى كند (• (T). لذا با در نظر كرفتن مطالب كَفته شده و با توجه

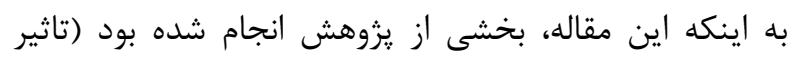

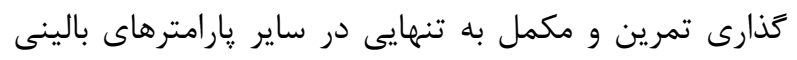
مربوط به كبد جرب به اثبات رسيده است)، لذا دور از از انتظار

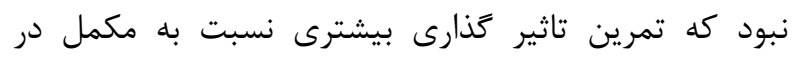
متغيرهاى فوق داشته باشد.

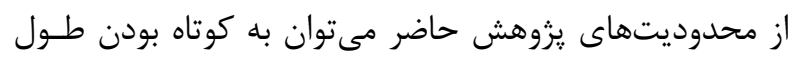

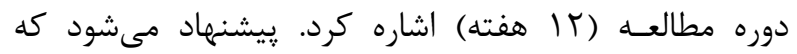

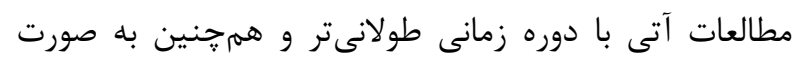

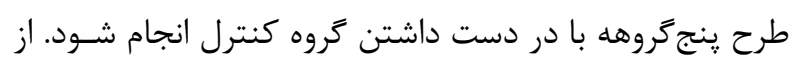

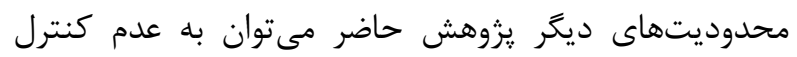

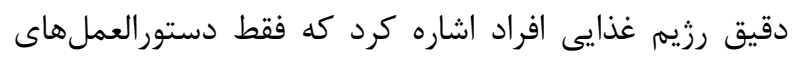

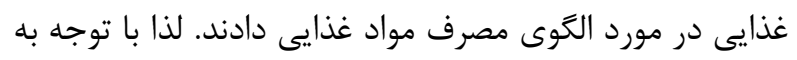

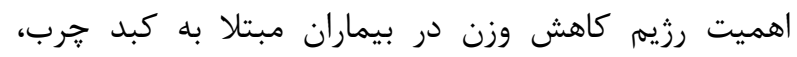

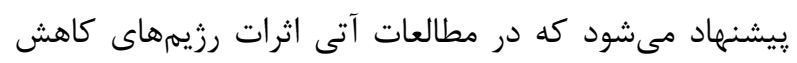

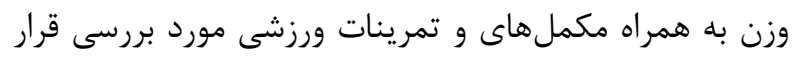

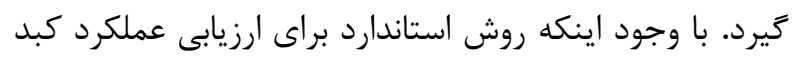

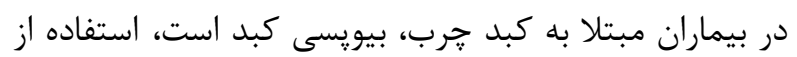

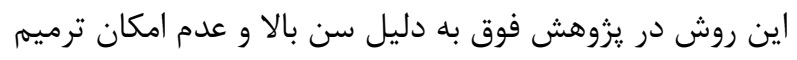

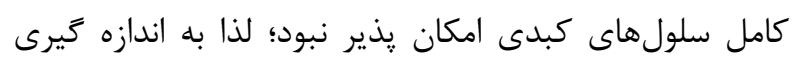
ساير پارامترها يرداخته شد. در مجموع نتايج يزوهش حاضر نشـان داد كـه تمرينـات بردات

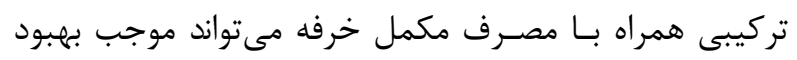

شدت •Q-V درصد يك تكرار بيشينه را در بيماران جاق

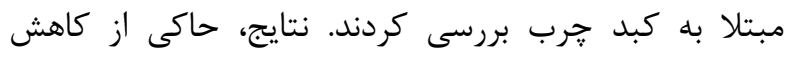

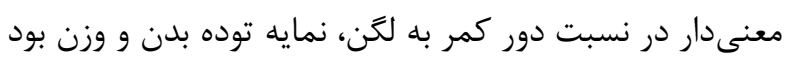
(Y)

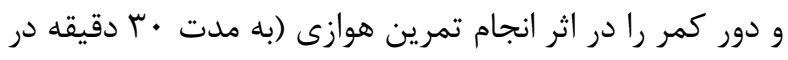

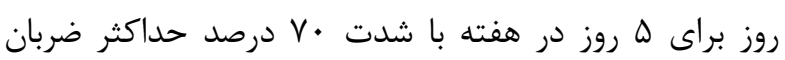

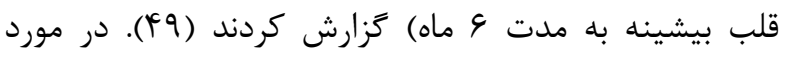

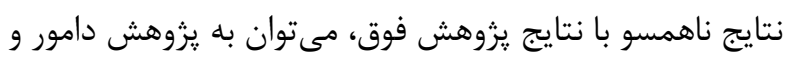

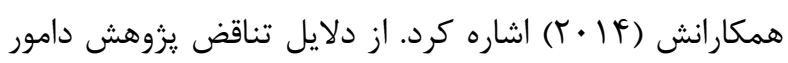

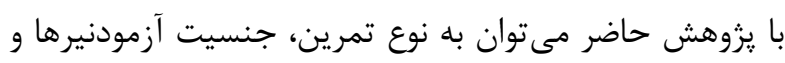

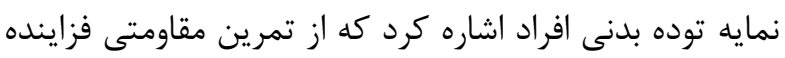

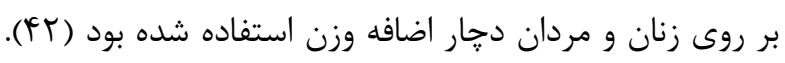

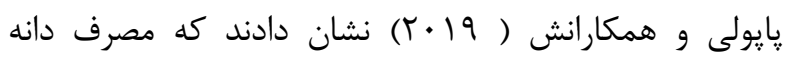

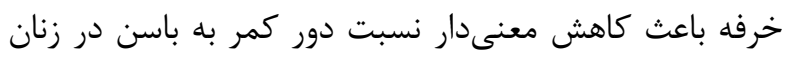

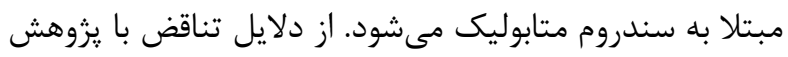

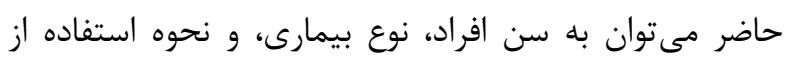

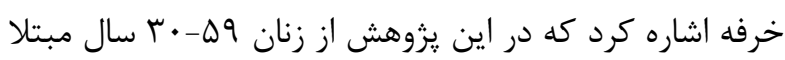

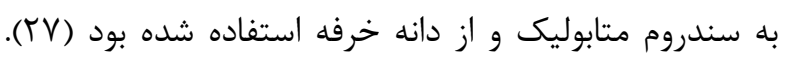

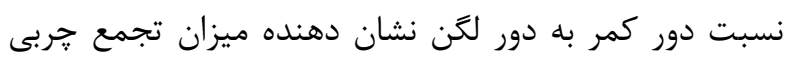

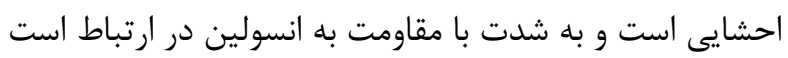

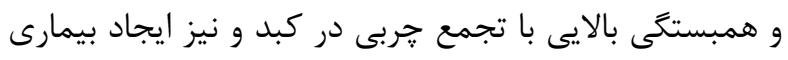

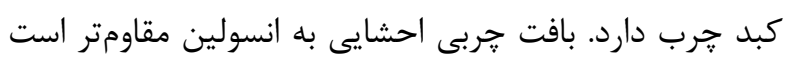

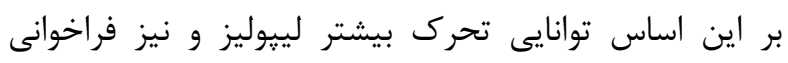

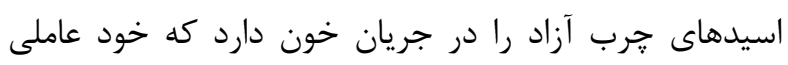

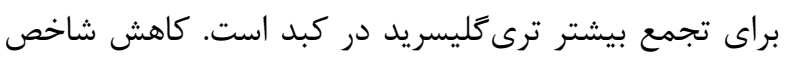

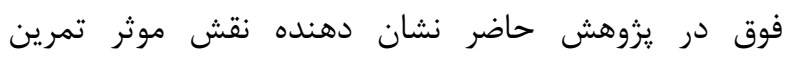

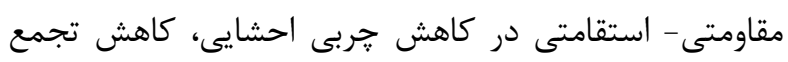

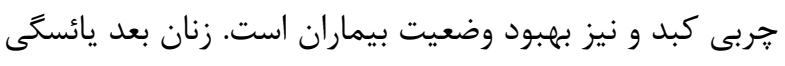

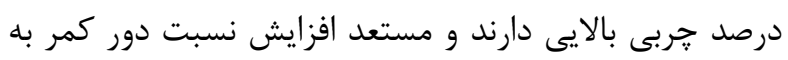
لكن هستند (• ده، 9).

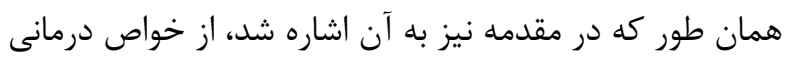

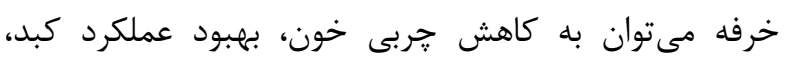

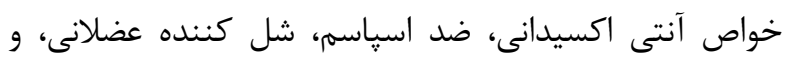

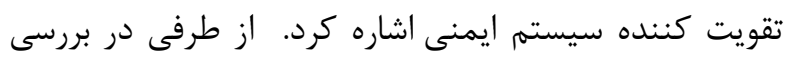

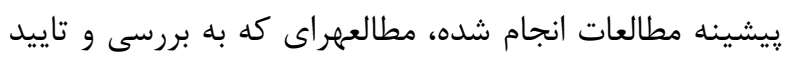
اثرات خرفه بر شاخصهاى منتخب تركيب بدن (نمايه توده

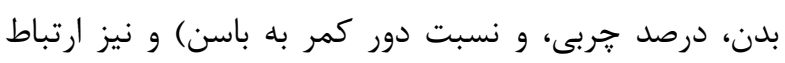

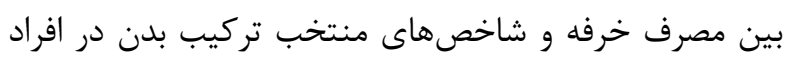

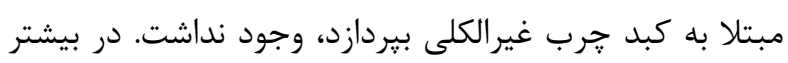

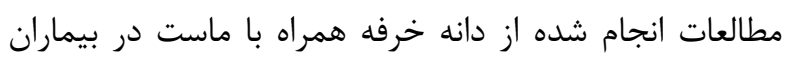




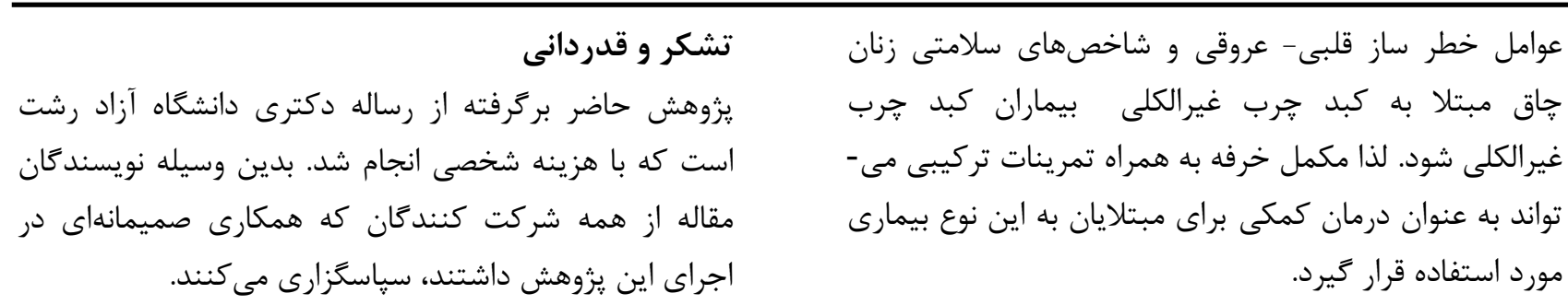

\section{REFERENCES}

1. Sahebkar Khorasani M, Yousefi M, Salari R, Bahrami-Taghanaki H, Behravanrad P. An evidence based review on integrative medicine in weight control. Complemen Med J 2017;1:1828-1850. [In Persian]

2. Safarpur M. Comparative study of anthropometric parameters in nonalcoholic fatty liver disease patients and healthy subjects. Sabzevar Univ Med Sci J 2015; 22: 225-231. [In Persian]

3. Bahmanabadi Z, Ebrahimi- Mamghani M, Arefhosseini SR. Comparision of low- calorie diet with and without sibutramine on body weight and liver function of patients with non- alcoholic fatty liver disease. Armaghan J 2010;16: 101-110. [In Persian]

4. Ghaemi AR, Taleban FA, Hekmatdoost A, Rafiei A, Hosseini V, Amiri Z, et al. Effect of weight reduction diet on non-alcoholic fatty liver disease. Nutrition Sci Food Technol 2013; 8: 123-132. [In Persian]

5. Farzanegi P, Salehi A. Effect of 8 weeks of resistance training with and without portulacalo seeds on some of liver injury markers in women with diabetes type 2. Univ Med Sci J 2015; 25: 968-978. [In Persian]

6. Nabizadeh A, SHabani R. Comparing effects of medication therapy and exercise training with diet on liver enzymes levels and liver sonography in patients with non- alcoholic fatty liver disease ( NAFLD). Fasa Univ Med Sci J 2016; 5: 488-500. [In Persian]

7. Zarei AS. Changizi Q Taheri S. Effect of purple extract on physiological function of body tissues. Qom Univ Med Sci J 2013; 8: Page 99-109. [In Persian]

8. Orangi E, Ostad Rahimi A, Mahdavi R, Somi M, Tarzemani M. Oxidative Stress-related parameters and antioxidant status in non-alcoholic fatty liver disease patients. Endocrin and Metabo J 2011; 12: 498-558. [In Persian]

9. Nikroo H, Nematy M, Sima HR, Attarzade SR, Pezeshkirad M, Esmaeilzadeh A, et al. Therapeutic effects of aerobic exercise and low-calorie diet on nonalcoholic steatohepatitis. Govaresh 2013; 17: 245- 53. [In Persian]

10. Li J, Wang F, Chen K, Xia Y, Lu J, Zhou Y, et al. Effects of physical activity on liver function in patients with nonalcoholic fatty liver disease: a meta-analysis. So J Immunol 2015; 3: 1-6.

11. Oh S, Shida T, Yamagishi k, Tanaka k, So R, Tsujimotot T, et al. Moderate to vigorous physical activity volume is an important factor for managing non- alcoholic fatty liver disease: a retrospective study. Hepatology J 2014; 3: 1-6.

12. Saremi Z, Rastgoo M, R Mohammadifard-bitabijari M, Akbari E. Comparision of platelet number and function between nonalcoholic fatty liver disease and normal individuals. J Res Med Sci 2017; 22 :75.

13. Sullivan S, Kirk EP, Mittendorfer B , Patterson BW. Randomized trial of exercise effect on intrahepatic triglyceride content and lipid kinetics in non-alcoholic fatty liver disease. Hepatology J 2012; 55: 1738-1745.

14. Nur A, Balahan M. Mean platelet volume in obese adolescents with nonalcoholic fatty liver disease. J Pediatr Endocrinol Metab. 2010;23:8-11.

15. Romero-Gómez M, Zelber-Sagi S, Trenell M. Treatment of NAFLD with diet, physical activity and exercise. J Hepatol. 2017;67:829-846.

16. Kaki A, Galedari M. The effect of 12 weeks high intensity interval training and resistance training on liver fat, liver enzymes and insulin resistance in men with nonalcoholic fatty liver. Jundishapur Sci Med J 2017; 16: $493-505$.

17. Moosavi- Sohroforouzani M, Ganbarzadeh M. Reviewing the physiological effects of aerobic and resistance training on insulin resistance and some biomarkers in non-alcoholic fatty liver disease. Kashan Univ Med Sci 2016; 20: 282- 296. [In Persian]

18. Shamsoddini A, Sobhani V, Chehreh MEG. Effect of Aerobic and Resistance Exercise Training on Liver Enzymes and Hepatic Fat in Iranian Men With Nonalcoholic Fatty Liver Disease. Hepat Mon 2015; 15: e31434.

19. Salehi A, Farzanegi P, Salehi A. Effect of 8 weeks of resistance training with and without portulacalo seeds on some of liver injury markers in women with diabetes type 2. Univ Med Sci 2015; 25: 968-978. [In Persian] 
20. Zarei A, Changizi - Ashtiyani S, Rasekh F, Mohamadi A, Gabari A. The effect of Physalis alkekengi extracts on lipids concentrations in rats. J Arak Univ Med Sci 2011; 14: 36-42.

22. Karimizandi L, Noorbakhshnia M, Ehsanpor AA, Rajaeyan S. Effect of hydro- alcoholic portulaca oleracea extract on oxidative damage induced bacterial lipopolysaccharide in liver of rat. Shahrekord Univ Med Sci 2016;17:124-135. [In Persian]

23. El-Sayed MI. Effects of portulaca oleraceal Seeds in treatment of type 2 diabetes. J Ethnopharmacol 2011; 13: 64351.

24. Esmaillzadeh A, Zakizadeh E, Faghihimani E, Gohari M, Jazayeri S. The effect of purslane seeds on glycemic status and lipid profiles of persons with type 2 diabetes: a randomized controlled cross-over clinical trial. J Res Med Sci $2015 ; 20: 47-53$.

25. Dehghan F, Soori R, Gholami Kh, Abolmaesoom M, Yusof A, Muniandy S, et al. Purslane (Portulaca oleracea) seed consumption and aerobic training improves biomarkers associated with atherosclerosis in women with type 2 diabetes (T2D). Sci Rep $2016 ; 6: 37819$.

26. Gheflati A, Adelina E, Nadjarzadeh A. The clinical effects of purslane (Portulaca oleracea) seeds on metabolic profiles in patients with nonalcoholic fatty liver disease: a randomized controlled clinical trial. Phytother Res 2019;33:1501-1509.

27. Papoli M, Pishdad S, Nadjarzadeh A, Hosseinzadeh M. Effects of consuming purslane seed powder on indicators of metabolic syndrome in women: a randomized clinical trial. Progr Nutr 2019; 21: 329-335.

28. Bedakhanian M, Entezari MH, Ghanadian M, Askari Gh, Maracy MR. The effects of Portulaca oleracea on lipid profile, c-reactive protein, and fasting blood glucose in men with metabolic syndrome: a double- blind randomized clinical trial. J Health Syst Res 2017; 12: 478- 483. [In Persian]

29. Besong SA. Ezekwe Mo. Ezekwe EI. Evaluating the effects of freeze- dried supplements of purslane on blood lipids in hypercholesterolemic adults. Int J Metab 2011; 3: 43-49.

30. Hoseini Kakhk SA, Khaleghzadeh H, Nematy M, Hamedinia M. The effect of combined aerobic- resistance training on lipid profile and liver enzymes in patients with non-alcoholic fatty liver under nutrition diet. Physiol Sport 2015; 27: 65-84. [In Persian]

31. Farzanegi P, Salehi A. Effect of 8 weeks of resistance training with and without portulacalo seeds on some of liver injury markers in women with diabetes type 2. Univ Med Scie 2015 ; 25: 968-978. [In Persian]

32. Gaine AA. Rajabi H, Eds. Physical readiness. Tehran: Samt; 2012. [In Persian]

33. Azarbayjani MA, Abedi B. Comparison of Aerobic, Resistance and Concurrent Exercise on Lipid Profiles and Adiponectin in Sedentary Men. Knowledge and Health J , Shahrood Univ Med Sci 2012; 7: 32-38.

34. Davoodi M, Haghighat GHA, Raoufi A, eds. Fatty liver disease and physical activity. Khorramabad: Larestan Univ Med Sci, Khaniran Publications; 2016. [In Persian]

35. Yavari AS. Najafipour F. Asgarzadeh A, Niafar M, Mobasseri M, Nikookheslat S. The effect of aerobic - resistance and combination exercises on glycemic control and cardiovascular risk factors in type 2 diabetic patients. Tabriz Univ Med Sci 2011; 33: 82-91. [In Persian]

36. Afshari M , Hossein Taghdisi M, Azam Kamal. The effect ofBASNEF-basedblended educational programonon diabetes control among type 2 diabetic patients referredto diabetes clinic of Samirom city. Razi J Medi Sci 2015; 22: $55-62$.

37. Jiffri O, Al- Sharif FM, Abd El-Kader SM, Ashmawy EM. Weight reduction improves markers of hepatic function and insulin resistance in type -2 diabetic patients with non-alcoholic fatty liver. African Health Science 2013;13: 66772.

38. Zelber - Sagi S, Ratziu V, Oren R. Nutrition and physical activity in NAFLD: an overview of the epidemiological evidence. World J Gastroenterol 2011; 17: 3377-3389.

39. Keshtkar L. The effect of 12 weeks of selected exercises on non-alcoholic fatty liver enzyme in postmenopausal women. Thesis. Government - Ministry of Science, Research and Technology, Urmia Univ, Faculty of Physical Education and Sport Sci 2013; 33: 82-91. [ in Persian]

40. Hoseini kakhk SA, Khaleghzadeh H, Nematy M, Hamedinia M. The effect of combined aerobic- resistance training on lipid profile and liver enzymes in patients with non-alcoholic fatty liver under nutrition diet. Physiol Sport 2015; 27: 65-84. [In Persian] 
41.Tazhibi M, Kelishadi R, Khalili Tahmasebi H, Adibi A, Beihaghi A, Salehi H.R, et al. Association of lifestyle with metabolic syndrome and non-Alcoholic fatty liver in children and adolescence. Hormozghan Univ Med Scie 2010; 14: 115-123. [In Persian]

42.Damor K, Mittalk K, Bhalla AS, Sood AN. Effect of progressive resistance exercise training on hepatic fat in Asian Indians with non-alcoholic fatty liver disease. Br Med Res J 2014; 4: 114-24.

43. Kotb M, El-Sayed MI. Effects of Portulaca oleraceal Seeds in treatment of type 2 diabetes. J Ethnopharmacol 2011;137: 643-51.

44. Yoshimura E, Kumahara H, Tobina T. A 12-week aerobic exercise program without energy restriction improves intrahepatic fat, liver function and atherosclerosis-related factors. Obes Res Clin Pract 2011;5:e169-e266.

45. Morad Al-Hasli F, Zahedi M, Abbasi M, Ahmadi C, Derwish Moghaddam P. The relationship between mesenteric fat thickness and fat accumulation in non-alcoholic fatty liver disease. J Southern Medicine, Persian Gulf Institute of Biomedical Research, Bushehr Univ Med Sci 2010 2010; 3: 189-180. [In Persian]

46. Ghorbanian B, Mohamadi H, Azali K. Effect of 10-week aerobic training with Rhus coriaria L supplementation on TAC, insulin resistance and anthropometric indices in women with type 2 diabetes. Complementary Med J 2017; 1: 1805-1815. [in Persian]

47. Ghibi SH, Tofighi A, Samadian Z, Saniei Y, Haji Ahmadi M. Study of changes in textures, serum liver and metabolic syndrome in patients with non-alcoholic fatty liver during a 36-session exercise. Applied Sport Physiology Research 2015; 26: 55-66. [In Persian]

48. Hallsworth K, Thoma C, Moore S, Ploetz T, Anstee Qm, Taylor R, et al. Non-alcoholic fatty liver disease is associated with higher levels of objectively measured sedentary behavior and lower levels of physical activity than matched healthy controls. Frontline Gasetoentero J 2015; 6: 44-51.

49. Bhat G, Baba CS, Pandey A, Kumari, N, Choudhuri G. Life style modification improves insulin resistance and liver histology in patients with non- alcoholic fatty liver disease. Word J Hepatol 2012; 4: 209-17.

50. Nikroo H, Nematy M, Sima HR, Attarzade SR, Pezeshkirad M, Esmaeilzadeh A, et al. Therapeutic effects of aerobic exercise and low-calorie diet on nonalcoholic steatohepatitis. Govaresh 2013; 17: 245- 53. [In Persian] 